\title{
Mapping anthropogenic nitrogen through point sources in coral reefs using $\delta^{15} \mathrm{~N}$ in macroalgae
}

\author{
Hsing-Juh Lin ${ }^{1,2, *}$, Chen-Yi Wu1 ${ }^{1}$, Shuh-Ji Kao ${ }^{3}$, Wen-Yuan Kao ${ }^{4}$, Pei-Jie Meng ${ }^{5}$ \\ ${ }^{1}$ Department of Life Sciences, National Chung Hsing University, Taichung 402, Taiwan, ROC \\ ${ }^{2}$ Institute of Marine Environmental Chemistry and Ecology, National Taiwan Ocean University, Keelung 202, Taiwan, ROC \\ ${ }^{3}$ Research Center for Environmental Change, Academia Sinica, Taipei 115, Taiwan, ROC \\ ${ }^{4}$ Department of Life Science, National Taiwan University, Taipei 106, Taiwan, ROC \\ ${ }^{5}$ National Museum of Marine Biology and Aquarium, Pingtung 944, Taiwan, ROC
}

\begin{abstract}
To trace anthropogenic $\mathrm{N}$ from sewage outfalls in coral reefs of Nanwan Bay, southern Taiwan, we analyzed tissue $\mathrm{N}, \mathrm{C} / \mathrm{N}$ ratio, and $\delta^{15} \mathrm{~N}$ values of macroalgae along horizontal lines parallel to the shoreline in the intertidal zone, and vertical transects perpendicular to the shoreline from the intertidal to the subtidal zone. Dominant macroalgal species in the intertidal and subtidal zones from 2 pristine islands, which were assumed to be little affected by human activities, were also collected for comparison. In total, 34 macroalgal species were collected for analysis in the wet and dry seasons to determine whether there was a seasonal effect. Low $\mathrm{N}$ contents and high $\mathrm{C} / \mathrm{N}$ ratios were observed in macroalgae with calcareous and leathery morphologies. However, the $\delta^{15} \mathrm{~N}$ values of macroalgae appeared to be little affected by the thallus forms. The $\mathrm{N}$ contents, C/N ratios, and $\delta^{15} \mathrm{~N}$ values of macroalgae growing on the reference transects or in the subtidal zone were similar to values of the same species or genera growing around the 2 pristine islands. On the horizontal lines or along the vertical transects, the $\mathrm{N}$ contents and $\mathrm{C} / \mathrm{N}$ ratios of macroalgae growing around the sewage-affected transects were not remarkably different (higher or lower) than the values of the same species growing around the reference transects. However, tissue $\delta^{15} \mathrm{~N}$ values of macroalgae showed a clear spatial pattern, with higher values around the sewage-affected transects and lower values around the reference transects in the intertidal zone, though the pattern was less distinct in the lower intertidal zone. Furthermore, $\delta^{15} \mathrm{~N}$ values in both seasons showed a clear curvilinear gradient along the sewage-affected transects, decreasing from the sewage outfalls to the subtidal zone, indicating that anthropogenic $\mathrm{N}$ loading was rapidly dispersed, with little evidence that the coral reefs in the subtidal zone were impacted by this nutrient source. Thus, $\delta^{15} \mathrm{~N}$ values of macroalgae can be sensitive biological indicators for anthropogenic N loading. Our results do not support the hypothesis that anthropogenic $\mathrm{N}$ enrichment is the major cause of the prolific growth of macroalgae on the coral reefs of Nanwan Bay.
\end{abstract}

KEY WORDS: $\delta^{15} \mathrm{~N} \cdot \mathrm{C} / \mathrm{N}$ ratio $\cdot \mathrm{N}$ content $\cdot$ Thallus form $\cdot$ Sewage $\cdot$ Tourist

Resale or republication not permitted without written consent of the publisher

\section{INTRODUCTION}

Coral reefs are in serious decline worldwide. Many coral reefs have lost their resilience (Bellwood et al. 2004) and have undergone rapid shifts from coral to macroalgal dominance (Smith et al. 1981, Done 1992, Hughes 1994, Grigg 1995). Determining the mecha- nisms for the phase shift in coral reefs has emerged as a common objective over the past decade. Anthropogenic nutrient enrichment can stimulate the prolific growth of macroalgae in coral reefs (Lapointe 1997) and has been considered among the most serious threats. Nevertheless, widespread replacement of corals by macroalgae might have resulted from coral 
mortality due to external disturbances, rather than competitive overgrowth (McCook et al. 2001). Jackson et al. (2001) attributed the decline in coral reefs worldwide to the combined effects of nutrient enrichment, resulting from human activities, and overfishing.

Despite the recent interest in macroalgae on coral reefs, support for the claim of anthropogenic nutrient enrichment as a major cause of the phase shift is equivocal (Szmant 2002). The common impression that the prolific growth of macroalgae on coral reefs reflects nutrient enrichment has been based, for the most part, on field observations, which have often shown positive correlations between macroalgal abundance and ambient nutrient concentrations in the water column (Hughes 1994, Jackson et al. 2001). However, rapid nutrient uptake by reef organisms indicates that nutrient concentrations in the water column alone are not adequate to assess the nutrient conditions of coral reefs (Koop et al. 2001). It is difficult to find a clear relationship between terrestrially derived nitrogen (N) inputs and macroalgal biomass (Umezawa et al. 2002b). Direct evidence showing that macroalgae in coral reefs benefit from anthropogenic nutrient enrichment is still lacking.

Natural stable $\mathrm{N}$ isotopes $\left({ }^{15} \mathrm{~N}:{ }^{14} \mathrm{~N}\right.$, conventionally expressed as $\delta^{15} \mathrm{~N}$ ) have been useful in detecting anthropogenic $\mathrm{N}$ loading. Sewage-derived wastewater is often highly enriched in $\delta^{15} \mathrm{~N}$, due to $\mathrm{N}$ transformations. Consequently, $\delta^{15} \mathrm{~N}$ values of plants and animals are higher at sewage-affected sites (McClelland et al. 1997, Fry 1999, Jones et al. 2001). It has been suggested that $\delta^{15} \mathrm{~N}$ values of coral tissue and macroalgae on coral reefs be used as biological indicators of anthropogenic $\mathrm{N}$ assimilation and for evaluating timeintegrated effects (Sammarco et al. 1999, Heikoop et al. 2000, Gartner et al. 2002, Umezawa et al. 2002b) that are missed by simply monitoring $\mathrm{N}$ concentrations in the water column. With increasing pressure on coral reefs, mapping of areas affected by anthropogenic $\mathrm{N}$ loading is required for more-effective management to conserve existing reefs and to restore those that are degraded.

Nanwan Bay, in the central part of Kenting National Park, is located on the southern tip of Taiwan (Fig. 1; $21^{\circ} 57^{\prime} \mathrm{N}, 120^{\circ} 44^{\prime} \mathrm{E}$ ). It is a semi-enclosed embayment bounded by 2 capes with well-developed fringing reefs distributed along the shoreline (Fig. 1). Millions of tourists visit Kenting National Park annually to experience the diving and tropical coastal atmosphere (www.ktnp.gov.tw/eng/home/index.asp). A significant disturbance exists from excessive nutrient loading into Nanwan Bay through sewage outfalls that carry untreated wastes and human feces. High proportions ( 10 to $55 \%$ ) of the reef area were occupied by macroalgae in a 1992 survey (Dai 1993). These seaweed blooms were often composed of opportunistic algae in the genera Enteromorpha, Ulva, Gracilaria, Laurencia, and Sargassum. The aims of this study were (1) to trace anthropogenic $\mathrm{N}$ in macroalgae on coral reefs horizontally from the outfalls in the intertidal zone, and (2) vertically from the outfalls in the intertidal zone to the reef's outer limits in the subtidal zone, (3) to determine whether assimilation of anthropogenic $\mathrm{N}$ in macroalgae differs among the various thallus forms, and (4) between the dry and wet seasons.

\section{MATERIALS AND METHODS}

Study sites. Nanwan Bay has a tropical climate, with distinct dry and wet seasons. The maximum air temperature (about $28^{\circ} \mathrm{C}$ ) often occurs in July, and the minimum (about $20^{\circ} \mathrm{C}$ ) occurs in January (statistics from the Central Weather Bureau, 1971 to 2000). In the wet season from May to October, average monthly rainfall may frequently exceed $320 \mathrm{~mm}$ when monsoon winds and typhoons bring considerable quantities of precipitation. During the dry season from November to April, when northeasterly winds prevail, mean monthly rainfall normally does not exceed $60 \mathrm{~mm}$.

Since no large river flows into Nanwan Bay, water column salinity varies within a small range of 32.6 to 34.7 psu (Lin \& Shao 1998). Chlorophyll a concentrations and the light extinction coefficient $(k)$ in the water column remain low, with ranges of 0.14 to $0.29 \mathrm{mg} \mathrm{m}^{-3}$ and 0.59 to $1.26 \mathrm{~m}^{-1}$, respectively. Circulation in the bay is dominated by mixed diurnal and semidiurnal tides, which are modulated by a pronounced spring-neap cycle (Lee et al. 1999). The tidal range reaches $1.6 \mathrm{~m}$ during spring tides, but is reduced to about $0.6 \mathrm{~m}$ during neap tides. Southward of Nanwan Bay, the prevailing tidal currents are westward during flood tides and eastward during ebb tides (Fig. 1a). In the eastern half of the bay, tidal currents regularly reverse following rises and falls in sea level. In the western half of the bay, however, there is daily periodic upwelling as the tidal current ebbs during spring tides, which results from cyclonic eddy pumping induced by the combined effects of tidal flow and topography (Lee et al. 1999). This tidally induced upwelling often causes sudden daily temperature drops in Nanwan Bay, commonly exceeding $10^{\circ} \mathrm{C}$. Speeds of tidal currents range up to $1.70 \mathrm{~m} \mathrm{~s}^{-1}$ near the 2 capes, decreasing by an order of magnitude in the shallow inner reaches of the bay.

Water column nutrient concentration and loading. Anthropogenic $\mathrm{N}$ loading into Nanwan Bay was estimated by multiplying the concentrations of dissolved inorganic nitrogen (DIN) and dissolved organic nitrogen (DON) in 17 sewage outfalls along the coast 


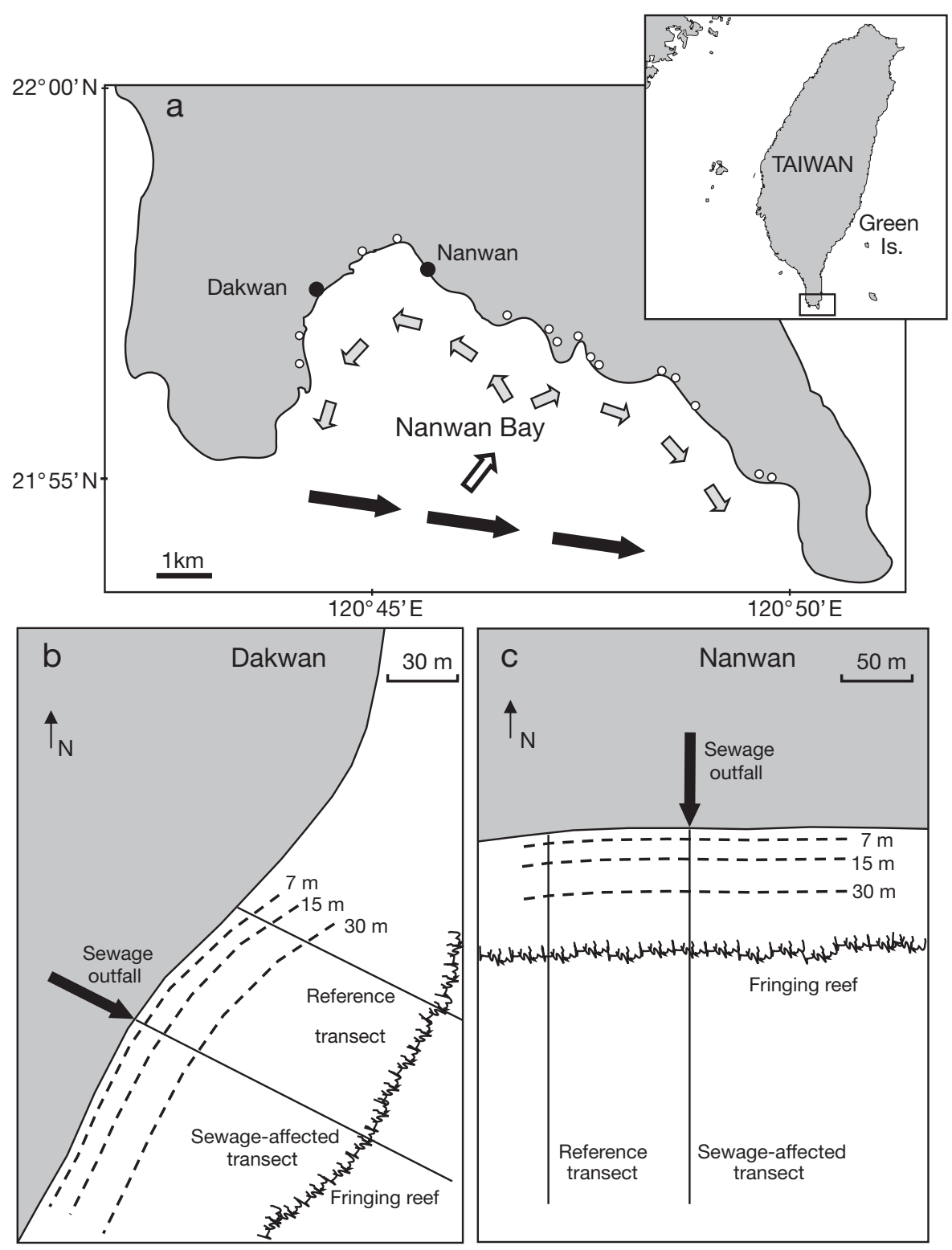

Fig. 1. (a) The 17 sampling sites (circles) for sewage effluents along the coast of Nanwan Bay. The schematic shows the development of a cyclonic circulation eddy as the tidal current ebbs during spring tides. The open arrow indicates the ascending shoreward flow which feeds the diverging flow in the bay. Locations of the 3 horizontal lines and 2 vertical transects relative to the sewage outfalls at (b) Dakwan and (c) Nanwan are shown

(Fig. 1a) by the wastewater flux (Umezawa et al. 2002a). Because nutrients flowing into sewers might be largely derived from wastes and feces of tourists, the wastewater flux of each sewer was determined bimonthly from the cross-sectional area and the mean water velocity of the profile for $48 \mathrm{~h}$ across a weekday (few tourists) and a holiday (abundant tourists) using SonTek/YSI FlowTracker ADV (Acoustic Doppler Velocimeter).

At each site, water samples for analyses of DIN and dissolved inorganic phosphorus (DIP: $\mathrm{PO}_{4}{ }^{3-}$ ) were col- lected at the outfall on the sewage-affected transect and in the subtidal zone every 1 to 2 mo from 2002 to 2003. In the laboratory, each water sample was filtered through precombusted (at $450^{\circ} \mathrm{C}$ for $4 \mathrm{~h}$ ) Whatman GF/F filters. Dissolved inorganic nitrogen (DIN: $\mathrm{NH}_{4}{ }^{+}+\mathrm{NO}_{3}{ }^{-}+\mathrm{NO}_{2}{ }^{-}$) and DIP were determined colorimetrically (Strickland \& Parsons 1972) with a flow injection analysis method (Pai \& Yang 1990). DON concentrations data were derived from Chen et al. (2004).

Field collections. Using a block design, 2 major outfalls were chosen to trace anthropogenic $\mathrm{N}$ in macro- 
algae on coral reefs on the coast of Nanwan Bay: one located at Dakwan (Fig. 1b) on the west side of the bay and the other situated at Nanwan (Fig. 1c) on the east side. The intertidal zones at Dakwan and Nanwan are 100 and $40 \mathrm{~m}$ wide, respectively. In order to horizontally trace anthropogenic $\mathrm{N}$ in macroalgae growing in the intertidal zone, three $300 \mathrm{~m}$ parallel lines at distances of 7,15 , and $30 \mathrm{~m}$ from the shoreline were laid out at each site with their centers lying at the outfall. Macroalgae were sampled at $5 \mathrm{~m}$ intervals along the $15 \mathrm{~m}$ lines in August 2003 and along the 7 and $30 \mathrm{~m}$ lines in August 2005 (wet season).

In order to vertically trace the anthropogenic $\mathrm{N}$ in macroalgae on coral reefs in Nanwan Bay, the seaweeds were sampled at $5 \mathrm{~m}$ intervals along 4 vertical transects, which were parallel to each other and perpendicular to the shoreline. The length of each transect ranged from 60 to $240 \mathrm{~m}$, depending upon the width of the fringing reefs, and extended seaward from the upper intertidal zone to the outer limits of the subtidal zone where most macroalgae disappeared at a depth of about $10 \mathrm{~m}$. At each site, the beginning of the sewage-affected transect was situated at the outfall. The beginning of the reference transect was separated from the sewage-affected transect by a distance of $>100 \mathrm{~m}$ and was apparently not influenced by the sewage effluents. In a few seagrass beds scattered on the transects, no macroalgal samples were available. To characterize discharge changes between the dry and wet seasons, macroalgal samples were collected in July to August 2002 (wet season) and January to March 2003 (dry season).

For comparison, dominant macroalgal species in the intertidal and subtidal zones were collected for measurements in January-March 2003 (dry season) from 2 pristine islands assumed to be little affected by human activities. Three study sites (Chaikou, Shihlang, and Dabaisha) around Green Island ( $\left.22^{\circ} 39^{\prime} \mathrm{N}, 121^{\circ} 28^{\prime} \mathrm{E}\right)$, which is lightly inhabited and located $33 \mathrm{~km}$ offshore from southeastern Taiwan, were selected for sampling. This island is about $5 \mathrm{~km}$ long and $4 \mathrm{~km}$ wide, with an area of $16.3 \mathrm{~km}^{2}$. The other island is Dongsha Island $\left(20^{\circ} 42^{\prime} \mathrm{N}, 116^{\circ} 43^{\prime} \mathrm{E}\right)$, also known as Pratas Island, which is uninhabited and located about $480 \mathrm{~km}$ southwest of Taiwan. It is $2.80 \mathrm{~km}$ long and $0.87 \mathrm{~km}$ wide, with an area of $1.74 \mathrm{~km}^{2}$.

Thallus samples were washed vigorously with distilled water to remove epiphytes and extraneous sediments. Calcareous thalli were decalcified with dilute $\mathrm{HCl}$. These samples were then freeze-dried and ground for analyses of tissue carbon $(\mathrm{C})$ and $\mathrm{N}$ contents and stable $\mathrm{N}$ isotopes.

Tissue carbon and nitrogen contents and stable isotopes. Tissue $\mathrm{C}$ and $\mathrm{N}$ contents and stable $\mathrm{N}$ isotopes of macroalgae were determined with a continuous-flow isotope ratio mass spectrometer (Finnigan delta S) coupled with an elemental analyzer (Carlo Erba NA 1500 NCS). Each macroalgal sample (3.00 to $6.00 \mathrm{mg}$ dry weight) was treated individually. Stable $\mathrm{N}$ isotopic data were reported as the relative difference between ratios of a sample and standards in standard notation as:

$$
\delta^{15} \mathrm{~N}(\%)=\left[\left(R_{\text {sample }} / R_{\text {standard }}\right)-1\right] \times 10^{3}
$$

where $R={ }^{15} \mathrm{~N} /{ }^{14} \mathrm{~N}$. $\delta^{15} \mathrm{~N}$ is the parts per thousand (\%o) deviation of that sample from the recognized $\mathrm{N}$ isotope standard, i.e. atmospheric $\mathrm{N}_{2}$ (Gearing 1991). The precision of the measurements was $\pm 0.1 \%$.

Statistical analyses. A 2-way fixed factor ANOVA model was used to determine whether water column nutrient concentrations and flows, and monthly $\mathrm{N}$ loadings of sewage effluents, differed between the 2 sites (Dakwan and Nanwan) and between the 2 seasons (the dry and wet season). A regression was used to analyze the effects of tourist numbers and rainfall on the summed monthly $\mathrm{N}$ loading from all 17 creeks and sewage outfalls, including Dakwan and Nanwan, along the coast of Nanwan Bay. We used Student's $t$-tests to determine whether macroalgal coverage and biomass differed between the 2 sites and whether tissue $\mathrm{N}$ content, the $\mathrm{C} / \mathrm{N}$ ratio, and $\delta^{15} \mathrm{~N}$ values of the same species of macroalgae differed between the sewage-affected and reference transects and between Nanwan Bay and the pristine islands. Before the analyses, power transformations (Clarke \& Warwick 1994) were applied to the data to ensure that they conformed to the assumptions of parametric statistics. These univariate statistical calculations were produced using the SAS system (vers. 8.2).

\section{RESULTS}

\section{Nutrient concentrations and nitrogen loading}

In the subtidal waters of Dakwan and Nanwan, DIN and DIP concentrations remained low in the dry and wet seasons (Table 1). No distinct differences in DIN and DIP concentrations were detected between the 2 sites or between the 2 seasons ( $p>0.05,2$-way ANOVA).

In the sewage effluents, DIN $\left(\mathrm{NH}_{4}{ }^{+}+\mathrm{NO}_{2}{ }^{-}+\mathrm{NO}_{3}{ }^{-}\right)$ and DIP (as $\mathrm{PO}_{4}{ }^{3-}$ ) concentrations at both sites were much higher than those in the subtidal water (Table 1). $\mathrm{NH}_{4}{ }^{+}$often contributed $>90 \%$ of the composition of DIN concentrations in the sewage effluents and the subtidal water. Extremely high $\mathrm{NH}_{4}{ }^{+}$concentrations were observed at Nanwan in the dry season (there was a significant interaction between season and site, $p=$ 0.004, 2-way ANOVA), which might have been attrib- 
Table 1. Nutrient concentrations (mean \pm SE) in sewage effluents and subtidal water, and $\mathrm{N}$ loading rates per $\mathrm{km}$ shoreline at Dakwan and Nanwan in southern Taiwan. DON: dissolved organic nitrogen

\begin{tabular}{|c|c|c|c|}
\hline Site & $\mathrm{n}$ & Dakwan & Nanwan \\
\hline \multicolumn{4}{|c|}{ Sewage effluent } \\
\hline Sewer drain & & 10 & 10 \\
\hline \multicolumn{4}{|c|}{ Sewage flow $\left(\mathrm{m}^{3} \mathrm{~s}^{-1}\right)$} \\
\hline Dry season & 3 & $208 \pm 64$ & $1.16 \pm 0.82$ \\
\hline Wet season & 5 & $39.2 \pm 7.3$ & $11.4 \pm 6.4$ \\
\hline \multicolumn{4}{|l|}{$\mathrm{NH}_{4}^{+}(\mu \mathrm{M})$} \\
\hline Dry season & 3 & $17.6 \pm 5.4$ & $343 \pm 86$ \\
\hline Wet season & 5 & $16.1 \pm 5.9$ & $90.1 \pm 22.7$ \\
\hline \multicolumn{4}{|c|}{$\mathrm{NO}_{2}^{-}+\mathrm{NO}_{3}^{-}(\mu \mathrm{M})$} \\
\hline Dry season & 3 & $3.21 \pm 0.44$ & $1.16 \pm 0.22$ \\
\hline Wet season & 5 & $3.77 \pm 0.42$ & $5.61 \pm 1.10$ \\
\hline \multicolumn{4}{|l|}{ DON $(\mu \mathrm{M})$} \\
\hline Dry season & 2 & $1.63 \pm 0.18$ & $1.65 \pm 0.20$ \\
\hline Wet season & 2 & $4.07 \pm 0.21$ & $2.42 \pm 0.71$ \\
\hline \multicolumn{4}{|l|}{$\mathrm{PO}_{4}{ }^{3-}(\mu \mathrm{M})$} \\
\hline Dry season & 3 & $1.04 \pm 0.22$ & $7.55 \pm 1.89$ \\
\hline Wet season & 5 & $1.22 \pm 0.17$ & $2.94 \pm 0.63$ \\
\hline \multicolumn{4}{|c|}{ Monthly N loading ( $\mathrm{kg} \mathrm{N} \mathrm{mo}^{-1}$ ) } \\
\hline Dry season & 3 & $356 \pm 119$ & $19.6 \pm 13.8$ \\
\hline Wet season & 5 & $66.9 \pm 13.6$ & $23.3 \pm 5.9$ \\
\hline Yearly N loac & $\left.\mathrm{km}^{-1} \mathrm{yr}^{-1}\right)$ & 282 & 46 \\
\hline \multicolumn{4}{|c|}{ Subtidal water } \\
\hline \multicolumn{4}{|l|}{$\mathrm{NH}_{4}^{+}(\mu \mathrm{M})$} \\
\hline Dry season & 5 & $2.67 \pm 1.19$ & $2.22 \pm 0.99$ \\
\hline Wet season & 8 & $2.50 \pm 0.88$ & $2.64 \pm 0.93$ \\
\hline \multicolumn{4}{|c|}{$\mathrm{NO}_{2}^{-}+\mathrm{NO}_{3}^{-}(\mu \mathrm{M})$} \\
\hline Dry season & 5 & $0.28 \pm 0.06$ & $0.25 \pm 0.05$ \\
\hline Wet season & 8 & $0.22 \pm 0.04$ & $0.23 \pm 0.04$ \\
\hline \multicolumn{4}{|l|}{$\mathrm{PO}_{4}{ }^{3-}(\mu \mathrm{M})$} \\
\hline Dry season & 5 & $0.07 \pm 0.02$ & $0.12 \pm 0.01$ \\
\hline Wet season & 8 & $0.08 \pm 0.03$ & $0.06 \pm 0.01$ \\
\hline
\end{tabular}

utable to the low flow of sewage effluents during this period. Concentrations of DON and $\mathrm{NO}_{2}{ }^{-}+\mathrm{NO}_{3}{ }^{-}$in the sewage effluents were similar at the 2 sites (higher in the wet season, $p=0.01,2$-way ANOVA). Sewage flow and monthly $\mathrm{N}$ (DIN + DON) loading rates were much higher at Dakwan than at Nanwan, especially in the dry season (there was a significant interaction between season and site, $p=0.02,2$-way ANOVA). Yearly $\mathrm{N}$ loading rates per unit length of shoreline were estimated to be 282 and $46 \mathrm{Mg} \mathrm{N} \mathrm{km}^{-1} \mathrm{yr}^{-1}$ at Dakwan and Nanwan, respectively.

Summing monthly $\mathrm{N}$ loading from all 17 creeks and sewer drains along the coast of Nanwan Bay, $78 \%$ of the variation in monthly $\mathrm{N}$ loadings from the coast into the bay can be explained to a large extent by numbers of tourists visiting the bay (Fig. 2a), while rainfall explains only $56 \%$, and the relationship is marginally significant (Fig. 2b).

\section{Macroalgal community structure}

In total, 34 macroalgal species on the coast of Nanwan Bay were collected for $\mathrm{N}$ analyses along the horizontal lines and vertical transects during the study period. Macroalgal coverage (mean $\pm \mathrm{SE}, \mathrm{n}=8$ ) reached $21.3 \pm 3.7 \%$ and $27.1 \pm 4.2 \%$ at Dakwan and Nanwan, respectively, and no significant difference was detected between the 2 sites ( $t$-test, $\mathrm{p}=0.30$ ). The spatial pattern of macroalgal biomass (mean wet mass [WW] \pm standard error, $\mathrm{n}=4$ ) followed that of coverage

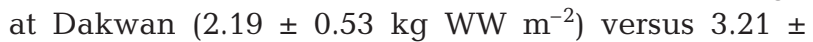
$0.52 \mathrm{~kg} \mathrm{WW} \mathrm{m}{ }^{-2}$ at Nanwan ( $t$-test, $\mathrm{p}=0.23$ ). Greater numbers of macroalgal species were observed in winter (dry season) than in summer (wet season). Dominant species observed at both sites in both seasons were similar, but differed between the intertidal and subtidal zones. While the intertidal zone was dominated by the chlorophytes Enteromorpha intestinalis, E. prolifera, and Ulva lactuca and the rhodophyte Gracilaria coronopifolia, the rhodophytes Galaxaura oblongata, Plocamium telfairiae, and Laurencia brongniartii dominated in the subtidal zone. The thallus or functional forms were primarily of filamentous, foliose, and coarsely branched forms (Littler \& Littler 1980).

\section{Tissue carbon and nitrogen contents}

In this study, tissue $\mathrm{N}$ contents of macroalgae paralleled those revealed by tissue $\mathrm{C} / \mathrm{N}$ ratios. In the intertidal zone at Dakwan, the $\mathrm{C} / \mathrm{N}$ ratios of macroalgae growing along the $7 \mathrm{~m}$ horizontal line were lower than those of seaweeds growing along the 15 and $30 \mathrm{~m}$ lines (Fig. 3). No distinct difference in the $\mathrm{C} / \mathrm{N}$ ratio was detected between the macroalgae growing around the sewage-affected and reference transects. Along the $15 \mathrm{~m}$ line in the mid-intertidal zone, the $\mathrm{C} / \mathrm{N}$ ratios around the sewage-affected transect remained low, but those around the reference transect increased. Along the $30 \mathrm{~m}$ line in the lower intertidal zone, the $\mathrm{C} / \mathrm{N}$ ratios of macroalgae increased slightly, and no distinct difference in the $\mathrm{C} / \mathrm{N}$ ratios was observed between the macroalgae growing around the sewageaffected and those on the reference transects. At Nanwan, the $\mathrm{C} / \mathrm{N}$ ratios of macroalgae were generally higher than those growing at Dakwan. No distinct differences in the $\mathrm{C} / \mathrm{N}$ ratios were detected between the macroalgae growing around the reference and sewage-affected transects on the 3 horizontal lines (Fig. 4). Significantly higher N contents (3.38 to $3.63 \%$ vs. 2.19 to $2.95 \%$ ) and lower $\mathrm{C} / \mathrm{N}$ ratios (10.6 to 13.4 vs. 12.7 to 19.4$)$ were detected in Enteromorpha intestinalis and E. prolifera samples growing within a distance of $25 \mathrm{~m}$ of the sewage-affected transect than 

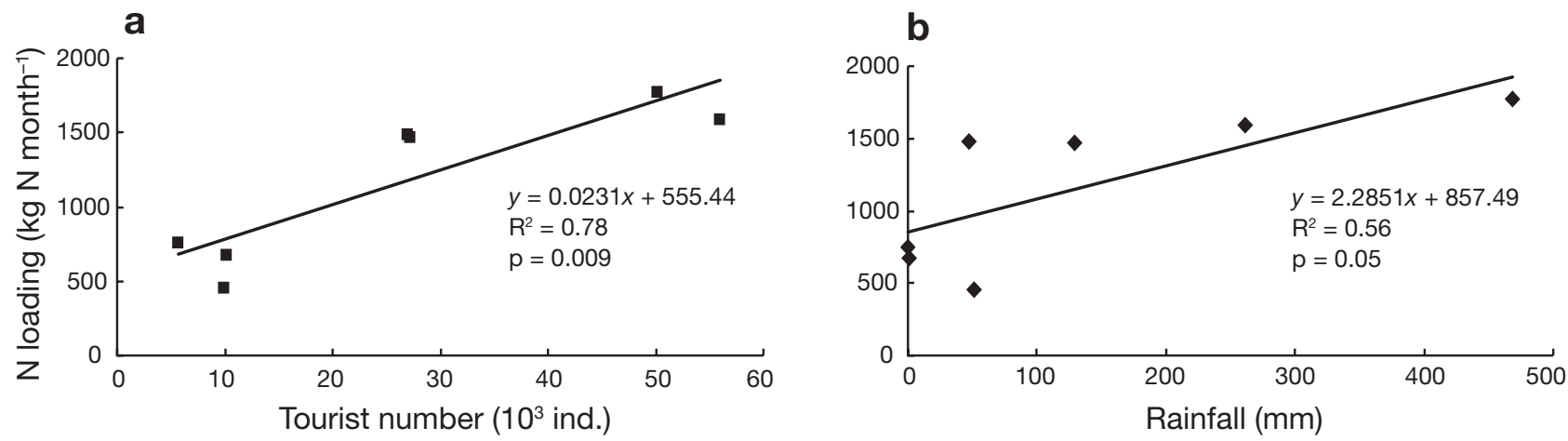

Fig. 2. Regression analysis of monthly N loading against (a) tourist number and (b) rainfall from 2002 to 2003

those of thalli on the reference transect at Dakwan, but not at Nanwan (Table 2). No clear relationships of the $\mathrm{N}$ contents or the $\mathrm{C} / \mathrm{N}$ ratios with the thallus forms of macroalgae growing in the intertidal zone were observed.

Along the vertical transects at both sites, the $\mathrm{C} / \mathrm{N}$ ratios of macroalgae growing in the intertidal zone appeared more variable than those growing in the subtidal zone, regardless of whether they grew on the reference or sewage-affected transects (Fig. 5) or in which season the specimens were collected (Fig. 6). In the intertidal zone at both sites (0 to $100 \mathrm{~m}$ of Dakwan and 0 to $40 \mathrm{~m}$ of Nanwan), the $\mathrm{N}$ contents of Enteromorpha intestinalis, E. prolifera, Gracilaria coronopifo-

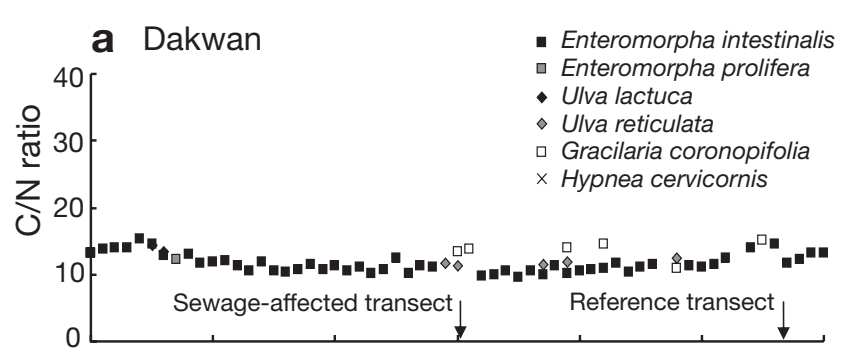

b
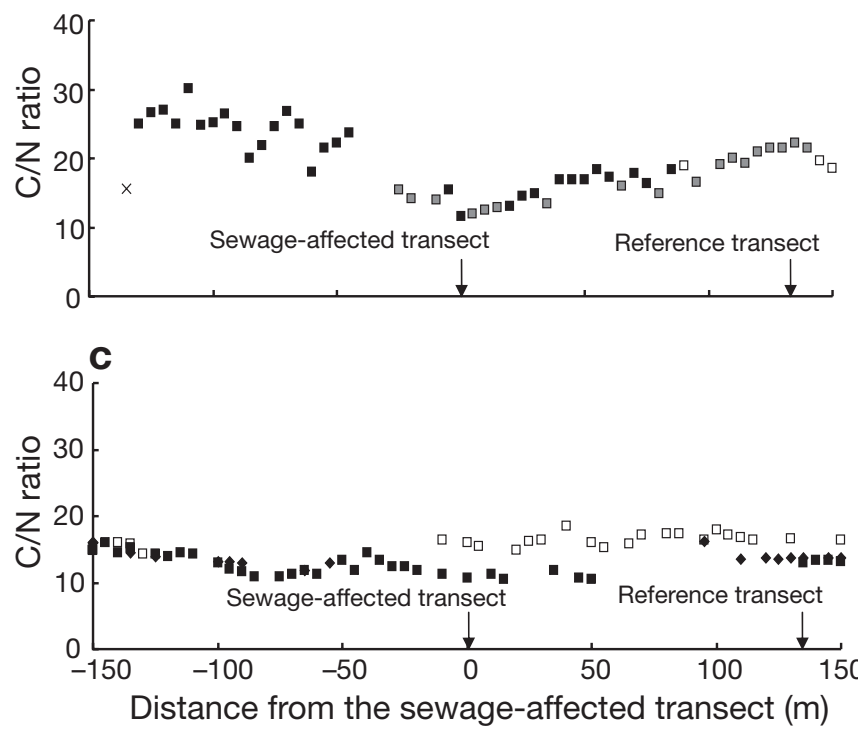

Fig. 3. C/N ratios of macroalgae collected from the horizontal lines, parallel to the shore at distances of (a) 7, (b) 15, and (c) $30 \mathrm{~m}$ at Dakwan in the wet seasons of 2003 and 2005
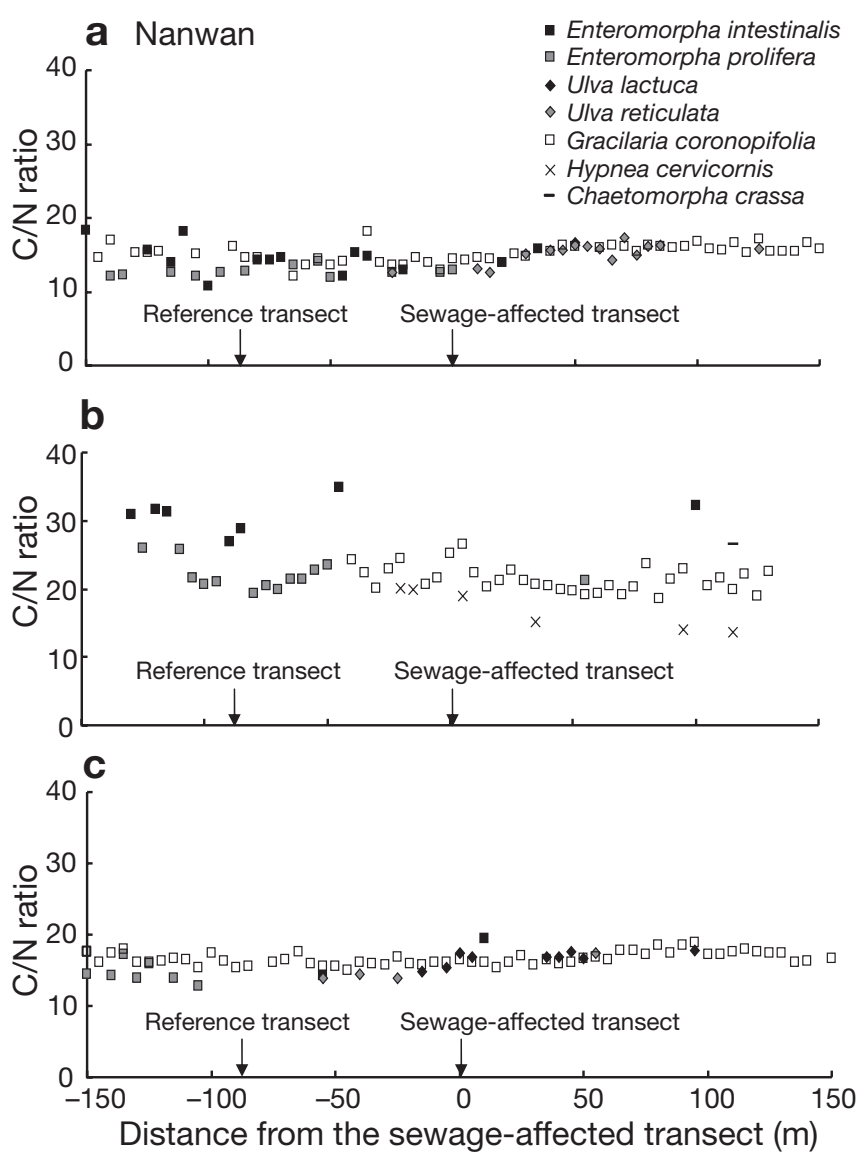

Fig. 4. $\mathrm{C} / \mathrm{N}$ ratios of macroalgae collected from the horizontal lines, parallel to the shore at distances of (a) 7, (b) 15, and (c) $30 \mathrm{~m}$ at Nanwan in the wet seasons of 2003 and 2005 
Table 2. Results of Student's $t$-test for differences in tissue $\mathrm{N}$ content, the $\mathrm{C} / \mathrm{N}$ ratio, and $\delta^{15} \mathrm{~N}$ of macroalgae growing within a distance of $25 \mathrm{~m}$ of the reference and sewage-affected transects on the 7, 15, and $30 \mathrm{~m}$ horizontal lines. Data are means \pm SE.

$$
{ }^{*} \mathrm{p}<0.05 ;{ }^{* *} \mathrm{p}<0.01{ }^{* * *} \mathrm{p}<0.001
$$

\begin{tabular}{|c|c|c|c|c|c|c|c|c|c|}
\hline Site & Species & $\mathrm{df}$ & N (\%) & $\begin{array}{c}\text { Reference } \\
\text { C/N }\end{array}$ & $\delta^{15} \mathrm{~N}(\%)$ & $\mathrm{N}(\%)$ & $\begin{array}{c}\text { Sewage } \\
\text { C/N }\end{array}$ & $\delta^{15} \mathrm{~N}(\% \circ)$ & $\begin{array}{l}\text { Thallus } \\
\text { form }\end{array}$ \\
\hline \multicolumn{10}{|c|}{ Dakwan } \\
\hline $7 \mathrm{~m}$ & $\begin{array}{l}\text { Enteromorpha } \\
\text { intestinalis }\end{array}$ & 16 & $2.95 \pm 0.11$ & $12.7 \pm 0.4$ & $5.63 \pm 0.16$ & $3.63 \pm 0.19^{* * *}$ & $10.6 \pm 0.4^{* * *}$ & $7.54 \pm 0.38^{* * *}$ & Filamentous \\
\hline $15 \mathrm{~m}$ & $\begin{array}{l}\text { Enteromorpha } \\
\text { prolifera }\end{array}$ & 14 & $2.19 \pm 0.05$ & $19.4 \pm 1.4$ & $4.29 \pm 0.15$ & $3.55 \pm 0.11^{* * *}$ & $13.4 \pm 0.5^{* * *}$ & $8.06 \pm 0.22^{* * *}$ & Filamentous \\
\hline \multirow[t]{2}{*}{$30 \mathrm{~m}$} & $\begin{array}{l}\text { Enteromorpha } \\
\text { intestinalis }\end{array}$ & 9 & $2.82 \pm 0.02$ & $13.2 \pm 0.1$ & $4.89 \pm 0.04$ & $3.38 \pm 0.13^{* *}$ & $11.3 \pm 0.3^{* * *}$ & $7.38 \pm 0.18^{* * *}$ & Filamentous \\
\hline & $\begin{array}{l}\text { Gracilaria } \\
\text { coronopifolia }\end{array}$ & 10 & $2.69 \pm 0.05$ & $16.9 \pm 0.3$ & $5.39 \pm 0.07$ & $2.82 \pm 0.08$ & $15.7 \pm 0.3^{* *}$ & $7.81 \pm 0.23^{* * *}$ & $\begin{array}{l}\text { Coarsely } \\
\text { branched }\end{array}$ \\
\hline \multicolumn{10}{|c|}{ Nanwan } \\
\hline \multirow[t]{3}{*}{$7 \mathrm{~m}$} & $\begin{array}{l}\text { Enteromorpha } \\
\text { intestinalis }\end{array}$ & 5 & $2.35 \pm 0.31$ & $14.8 \pm 0.8$ & $5.98 \pm 0.14$ & $2.59 \pm 0.25$ & $13.4 \pm 0.5$ & $7.40 \pm 0.11^{*}$ & Filamentous \\
\hline & $\begin{array}{l}\text { Enteromorpha } \\
\text { prolifera }\end{array}$ & 6 & $2.76 \pm 0.36$ & $13.9 \pm 0.4$ & $6.02 \pm 0.13$ & $3.02 \pm 0.07$ & $12.4 \pm 0.1$ & $6.54 \pm 0.09^{*}$ & Filamentous \\
\hline & $\begin{array}{l}\text { Gracilaria } \\
\text { coronopifolia }\end{array}$ & 21 & $2.84 \pm 0.04$ & $16.0 \pm 0.2$ & $4.56 \pm 0.08$ & $3.19 \pm 0.03^{* * *}$ & $14.2 \pm 0.2^{* * *}$ & $6.84 \pm 0.12^{* * *}$ & $\begin{array}{l}\text { Coarsely } \\
\text { branched }\end{array}$ \\
\hline \multirow[t]{3}{*}{$15 \mathrm{~m}$} & $\begin{array}{l}\text { Enteromorpha } \\
\text { intestinalis }\end{array}$ & 5 & $1.27 \pm 0.06$ & $31.3 \pm 0.2$ & $4.80 \pm 0.42$ & $1.37 \pm 0.23$ & $30.9 \pm 3.3$ & $6.61 \pm 0.22^{*}$ & Filamentous \\
\hline & $\begin{array}{l}\text { Enteromorpha } \\
\text { prolifera }\end{array}$ & 7 & $1.77 \pm 0.09$ & $23.5 \pm 1.1$ & $5.35 \pm 0.28$ & $2.05 \pm 0.03^{*}$ & $20.5 \pm 0.3^{*}$ & $8.67 \pm 0.18^{* * *}$ & Filamentous \\
\hline & $\begin{array}{l}\text { Gracilaria } \\
\text { coronopifolia }\end{array}$ & 15 & $2.11 \pm 0.05$ & $21.0 \pm 0.6$ & $4.07 \pm 0.08$ & $1.99 \pm 0.04$ & $22.8 \pm 0.6$ & $5.41 \pm 0.19^{* * *}$ & $\begin{array}{l}\text { Coarsely } \\
\text { branched }\end{array}$ \\
\hline $30 \mathrm{~m}$ & $\begin{array}{l}\text { Gracilaria } \\
\text { coronopifolia }\end{array}$ & 19 & $2.66 \pm 0.04$ & $17.2 \pm 0.2$ & $4.23 \pm 0.05$ & $2.79 \pm 0.02^{*}$ & $16.2 \pm 0.2^{*}$ & $4.66 \pm 0.10^{* * *}$ & $\begin{array}{l}\text { Coarsely } \\
\text { branched }\end{array}$ \\
\hline
\end{tabular}

lia, Plocamium telfairiae, and Padina australis on the sewage-affected transects were not clearly higher, and the $\mathrm{C} / \mathrm{N}$ ratios were not clearly lower than the values of respective species on the reference transects, which was partly attributable to the large variations observed within samples (Table 3 ). In the subtidal zone (>100 m at Dakwan and $>40 \mathrm{~m}$ at Nanwan), the $\mathrm{N}$ contents and $\mathrm{C} / \mathrm{N}$ ratios of Galaxaura oblongata, Laurencia brongniartii, and $P$. telfairiae growing on the reference and sewage-affected transects were similar (Table 3). G. oblongata, a calcareous rhodophyte, had extremely low $\mathrm{N}$ contents on both the sewage-affected and reference transects.

For the 2 pristine islands, lower $\mathrm{N}$ contents and higher $\mathrm{C} / \mathrm{N}$ ratios were also observed in macroalgae of the calcareous and leathery forms (Table 4). Their values were similar to those of the calcareous rhodophyte Galaxaura oblongata growing on the reference transect in Nanwan Bay. In the intertidal zone of Green Island, the $\mathrm{N}$ contents and $\mathrm{C} / \mathrm{N}$ ratios of the chlorophytes Ulva lactuca and Enteromorpha intestinalis were similar to the respective values of specimens growing around the reference transect in the intertidal zone of Nanwan Bay (Figs. 3 \& 4). In the subtidal zone of Dongsha Island, the $\mathrm{N}$ content and $\mathrm{C} / \mathrm{N}$ ratio of the rhodophyte Gracilaria canaliculata were comparable to those of the congener $G$. coronopifolia growing in the lower intertidal zone of Nanwan (Table 3).

\section{Tissue stable nitrogen isotopes}

In the intertidal zone of Dakwan and Nanwan, tissue $\delta^{15} \mathrm{~N}$ values of macroalgae showed a clear spatial pattern with higher values around the sewage-affected transects and lower values around the reference transects (Figs. $7 \&$ 8). However, the difference became small on the $30 \mathrm{~m}$ lines. $\delta^{15} \mathrm{~N}$ values of Enteromorpha intestinalis, E. prolifera, and Gracilaria coronopifolia growing around the sewage-affected transects were significantly higher than the values of the same species growing around the reference transects on all of the horizontal lines (Table 2).

In general, $\delta^{15} \mathrm{~N}$ values of intertidal macroalgae growing at Dakwan (Fig. 7) were more enriched than those growing at Nanwan (Fig. 8). At Dakwan, the $\delta^{15} \mathrm{~N}$ values of macroalgae growing on the south side of the sewage-affected transect on all of the horizontal lines remained high, with values of $>8 \%$ (Fig. 7). At Nanwan, some $\delta^{15} \mathrm{~N}$ values of $E$. prolifera on the west 


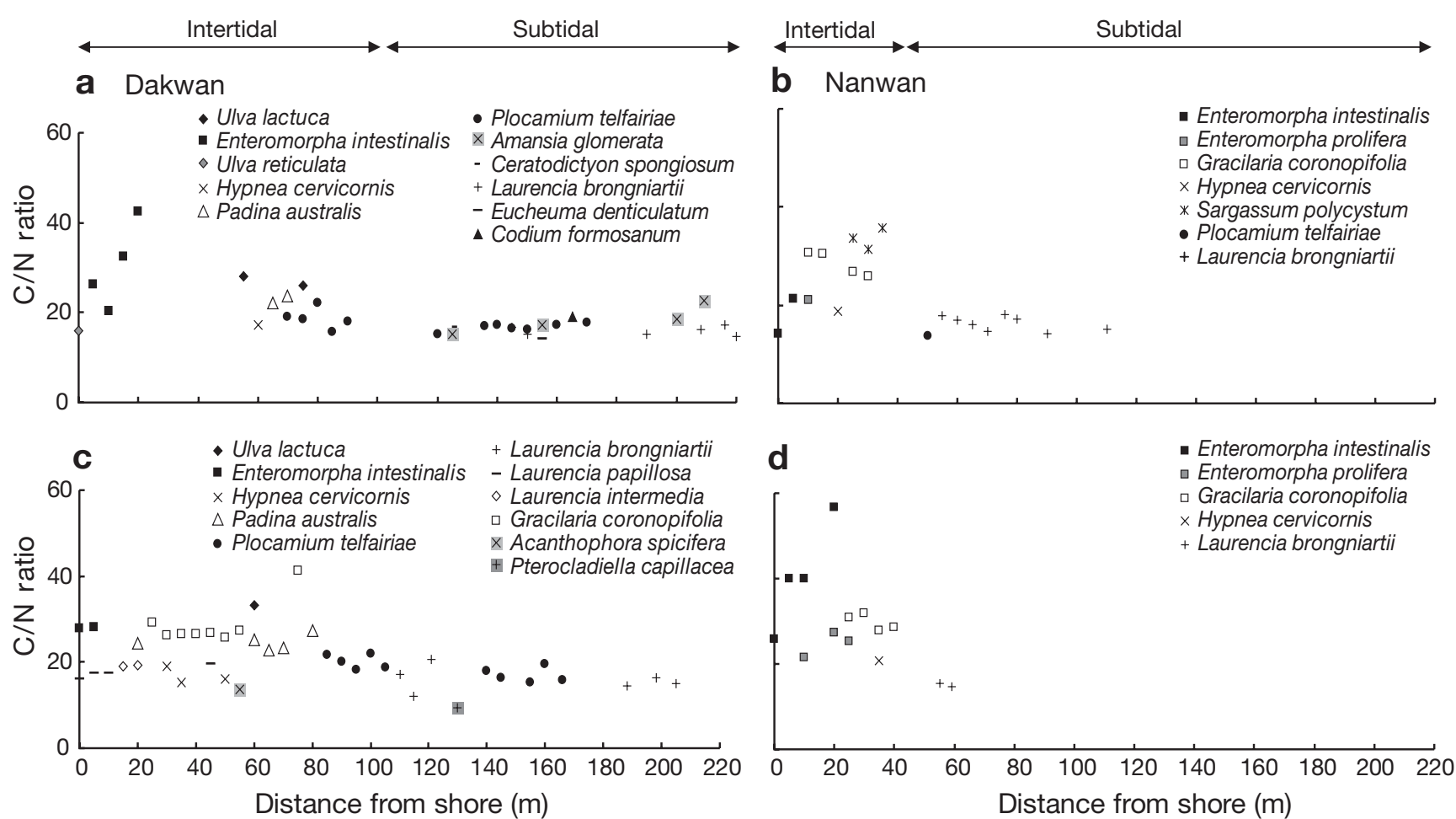

Fig. 5. C/N ratios of macroalgae collected from sewage-affected transects at (a) Dakwan and (b) Nanwan and from reference transects at (c) Dakwan and (d) Nanwan in the wet season of 2002

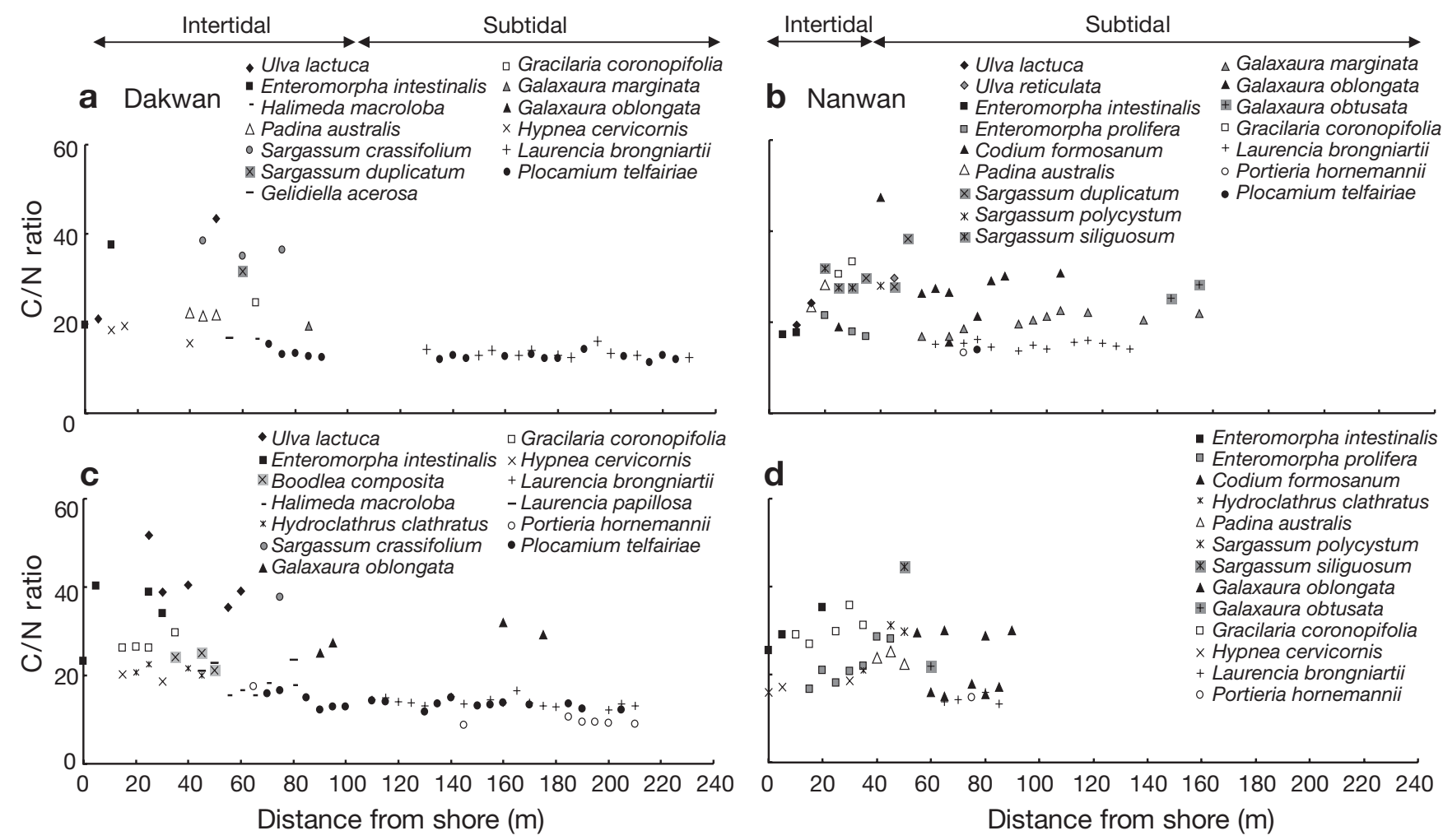

Fig. 6. C/N ratios of macroalgae collected from sewage-affected transects at (a) Dakwan and (b) Nanwan and from reference transects at (c) Dakwan and (d) Nanwan in the dry season of 2003 
Table 3. Results of Student's $t$-test for differences in tissue $\mathrm{N}$ content, the $\mathrm{C} / \mathrm{N}$ ratio, and $\delta^{15} \mathrm{~N}$ of macroalgae growing on the reference and sewage-affected transects. The intertidal zone is 0 to $100 \mathrm{~m}$ at Dakwan and 0 to $40 \mathrm{~m}$ at Nanwan. Data are means $\pm \mathrm{SE}$. ${ }^{*} \mathrm{p}<0.05{ }^{* *} \mathrm{p}<0.01 ;{ }^{* * *} \mathrm{p}<0.001$

\begin{tabular}{|c|c|c|c|c|c|c|c|c|c|}
\hline Site & Species & df & $\mathrm{N}(\%)$ & $\begin{array}{l}\text { Reference } \\
\text { C/N }\end{array}$ & $\delta^{15} \mathrm{~N}(\%)$ & $\mathrm{N}(\%)$ & $\begin{array}{c}\text { Sewage } \\
\text { C/N }\end{array}$ & $\delta^{15} \mathrm{~N}(\%)$ & $\begin{array}{l}\text { Thallus } \\
\text { form }\end{array}$ \\
\hline \multicolumn{10}{|c|}{ Wet season } \\
\hline \multicolumn{10}{|c|}{ Dakwan } \\
\hline $0-20 \mathrm{~m}$ & $\begin{array}{l}\text { Enteromorpha } \\
\text { intestinalis }\end{array}$ & 5 & $1.35 \pm 0.05$ & $27.9 \pm 0.1$ & $4.35 \pm 0.15$ & $1.18 \pm 0.21$ & $30.4 \pm 4.6$ & $8.00 \pm 0.23^{* * *}$ & Filamentous \\
\hline \multirow[t]{2}{*}{$20-100 \mathrm{~m}$} & $\begin{array}{l}\text { Padina } \\
\text { australis }\end{array}$ & 6 & $1.52 \pm 0.07$ & $24.5 \pm 0.79$ & $3.20 \pm 0.19$ & $1.35 \pm 0.05$ & $23.0 \pm 0.8$ & $5.85 \pm 0.35^{* * *}$ & Crustose \\
\hline & $\begin{array}{l}\text { Plocamium } \\
\text { telfairiae }\end{array}$ & 8 & $1.93 \pm 0.07$ & $20.5 \pm 0.84$ & $4.55 \pm 0.10$ & $1.94 \pm 0.13$ & $18.7 \pm 1.0$ & $7.14 \pm 0.21^{* * *}$ & $\begin{array}{l}\text { Coarsely } \\
\text { branched }\end{array}$ \\
\hline \multirow[t]{2}{*}{$>100 \mathrm{~m}$} & $\begin{array}{l}\text { Laurencia } \\
\text { brongniartii }\end{array}$ & 11 & $2.78 \pm 0.21$ & $16.0 \pm 1.2$ & $4.62 \pm 0.12$ & $2.60 \pm 0.09$ & $15.9 \pm 0.4$ & $5.15 \pm 0.16^{* *}$ & $\begin{array}{l}\text { Coarsely } \\
\text { branched }\end{array}$ \\
\hline & $\begin{array}{l}\text { Plocamium } \\
\text { telfairiae }\end{array}$ & 12 & $2.18 \pm 0.07$ & $17.3 \pm 0.7$ & $4.85 \pm 0.04$ & $2.11 \pm 0.04$ & $16.7 \pm 0.3$ & $4.93 \pm 0.10$ & $\begin{array}{l}\text { Coarsely } \\
\text { branched }\end{array}$ \\
\hline \multicolumn{10}{|l|}{ Nanwan } \\
\hline $0-20 \mathrm{~m}$ & $\begin{array}{l}\text { Enteromorpha } \\
\text { intestinalis }\end{array}$ & 5 & $0.96 \pm 0.16$ & $40.7 \pm 6.3$ & $4.61 \pm 0.12$ & $1.94 \pm 0.38^{*}$ & $17.8 \pm 3.5^{*}$ & $13.14 \pm 1.75^{* * *}$ & Filamentous \\
\hline $20-40 \mathrm{~m}$ & $\begin{array}{l}\text { Gracilaria } \\
\text { coronopifolia }\end{array}$ & 5 & $1.49 \pm 0.05$ & $29.8 \pm 1.0$ & $5.36 \pm 0.26$ & $1.77 \pm 0.03^{*}$ & $26.3 \pm 0.3^{*}$ & $4.41 \pm 0.10$ & $\begin{array}{l}\text { Coarsely } \\
\text { branched }\end{array}$ \\
\hline$>40 \mathrm{~m}$ & $\begin{array}{l}\text { Laurencia } \\
\text { brongniartii }\end{array}$ & 9 & $2.74 \pm 0.09$ & $15.0 \pm 0.4$ & $5.45 \pm 0.46$ & $2.53 \pm 0.11$ & $16.2 \pm 0.5$ & $4.86 \pm 0.09$ & $\begin{array}{l}\text { Coarsely } \\
\text { branched }\end{array}$ \\
\hline \multicolumn{10}{|c|}{ Dry season } \\
\hline \multicolumn{10}{|l|}{ Dakwan } \\
\hline $0-20 \mathrm{~m}$ & $\begin{array}{l}\text { Enteromorpha } \\
\text { intestinalis }\end{array}$ & 3 & $1.18 \pm 0.34$ & $31.8 \pm 8.5$ & $5.07 \pm 1.27$ & $1.51 \pm 0.52$ & $28.7 \pm 8.9$ & $8.58 \pm 1.50^{*}$ & Filamentous \\
\hline $20-100 \mathrm{~m}$ & $\begin{array}{l}\text { Plocamium } \\
\text { telfairiae }\end{array}$ & 10 & $2.74 \pm 0.15$ & $14.3 \pm 0.8$ & $4.61 \pm 0.03$ & $2.73 \pm 0.10$ & $13.4 \pm 0.5$ & $4.84 \pm 0.12^{*}$ & $\begin{array}{l}\text { Coarsely } \\
\text { branched }\end{array}$ \\
\hline \multirow[t]{2}{*}{$>100 \mathrm{~m}$} & $\begin{array}{l}\text { Laurencia } \\
\text { brongniartii }\end{array}$ & 26 & $3.39 \pm 0.08$ & $13.9 \pm 0.3$ & $3.88 \pm 0.07$ & $3.16 \pm 0.08^{*}$ & $13.5 \pm 0.3$ & $4.01 \pm 0.08^{*}$ & $\begin{array}{l}\text { Coarsely } \\
\text { branched }\end{array}$ \\
\hline & $\begin{array}{l}\text { Plocamium } \\
\text { telfairiae }\end{array}$ & 24 & $2.92 \pm 0.05$ & $13.3 \pm 0.2$ & $4.52 \pm 0.07$ & $2.88 \pm 0.05$ & $12.6 \pm 0.3^{*}$ & $4.68 \pm 0.06^{*}$ & $\begin{array}{l}\text { Coarsely } \\
\text { branched }\end{array}$ \\
\hline \multicolumn{10}{|l|}{ Nanwan } \\
\hline $0-20 \mathrm{~m}$ & $\begin{array}{l}\text { Enteromorpha } \\
\text { intestinalis }\end{array}$ & 4 & $1.22 \pm 0.11$ & $30.0 \pm 2.8$ & $5.15 \pm 0.37$ & $2.22 \pm 0.04^{*}$ & $17.5 \pm 0.2^{*}$ & $14.89 \pm 0.55^{* * *}$ & Filamentous \\
\hline \multirow[t]{2}{*}{$20-40 \mathrm{~m}$} & $\begin{array}{l}\text { Enteromorpha } \\
\text { prolifera }\end{array}$ & 7 & $1.91 \pm 0.15$ & $22.0 \pm 1.7$ & $4.62 \pm 0.48$ & $2.20 \pm 0.11$ & $18.7 \pm 1.4$ & $4.84 \pm 1.00$ & Filamentous \\
\hline & $\begin{array}{l}\text { Gracilaria } \\
\text { coronopifolia }\end{array}$ & 4 & $1.48 \pm 0.09$ & $32.2 \pm 1.9$ & $4.90 \pm 0.34$ & $1.53 \pm 0.07$ & $31.8 \pm 1.4$ & $4.89 \pm 0.05$ & $\begin{array}{l}\text { Coarsely } \\
\text { branched }\end{array}$ \\
\hline \multirow[t]{2}{*}{$>40 \mathrm{~m}$} & $\begin{array}{c}\text { Galaxaura } \\
\text { oblongata }\end{array}$ & 10 & $0.77 \pm 0.03$ & $29.6 \pm 0.3$ & $4.78 \pm 0.31$ & $0.89 \pm 0.08$ & $27.4 \pm 1.2$ & $4.40 \pm 0.20$ & calcareous \\
\hline & $\begin{array}{l}\text { Laurencia } \\
\text { brongniartii }\end{array}$ & 15 & $3.06 \pm 0.14$ & $14.4 \pm 0.6$ & $4.14 \pm 0.08$ & $3.14 \pm 0.05$ & $15.0 \pm 0.2$ & $4.08 \pm 0.07$ & $\begin{array}{l}\text { Coarsely } \\
\text { branched }\end{array}$ \\
\hline
\end{tabular}

side of the sewage-affected transect were highly enriched (Fig. 8b).

In the wet season at both sites, the $\delta^{15} \mathrm{~N}$ values of macroalgae growing along the sewage-affected transect showed a clear curvilinear gradient, from high values of 9.80 or $14.9 \%$ at the outfall of the sewer drains to low values of 2.75 or $3.12 \%$ in the subtidal zones (Fig. 9a,b). On the other hand, the $\delta^{15} \mathrm{~N}$ values of macroalgae growing along the reference transects remained low at 2.80 to $5.96 \%$ o (Fig. 9c,d). In the intertidal zone, the $\delta^{15} \mathrm{~N}$ values of Enteromorpha intestinalis, Padina australis, and Plocamium telfairiae at Dakwan, and of E. intestinalis at Nanwan growing on the sewage-affected transects were significantly higher than the values of the same species growing on the reference transects (Table 3 ). In the subtidal zone, however, only the $\delta^{15} \mathrm{~N}$ values of Laurencia brongniartii growing on the sewage-affected transect at 
Table 4. Tissue $\mathrm{N}$ content, the $\mathrm{C} / \mathrm{N}$ ratio, and $\delta^{15} \mathrm{~N}$ of macroalgae growing on the coasts of Green Island and Dongsha Island in the dry season. Data are means $\pm \mathrm{SE}$

\begin{tabular}{|c|c|c|c|c|c|c|c|}
\hline Site & Species & Zone & $\mathrm{n}$ & $\mathrm{N}(\%)$ & $\mathrm{C} / \mathrm{N}$ ratio & $\delta^{15} \mathrm{~N}(\%)$ & Thallus form \\
\hline \multicolumn{8}{|c|}{ Green Island } \\
\hline \multirow[t]{5}{*}{ Chaikou } & Ulva fasciata & Intertidal & 3 & $1.44 \pm 0.01$ & $25.7 \pm 0.1$ & $1.86 \pm 0.01$ & Foliose \\
\hline & Boodlea composite & Intertidal & 2 & $3.05 \pm 0.38$ & $13.4 \pm 0.5$ & $2.60 \pm 0.07$ & Finely branched \\
\hline & Gelidiella acerosa & Intertidal & 3 & $1.89 \pm 0.06$ & $18.9 \pm 0.4$ & $5.45 \pm 0.35$ & Coarsely branched \\
\hline & Yamadaella caenomyce & Intertidal & 3 & $0.81 \pm 0.02$ & $15.9 \pm 4.4$ & $4.22 \pm 0.66$ & Calcareous \\
\hline & Valoniopsis pachynema & Intertidal & 2 & $2.43 \pm 0.02$ & $14.6 \pm 2.5$ & $3.61 \pm 0.90$ & Finely branched \\
\hline \multirow[t]{5}{*}{ Shihlang } & Ulva lactuca & Intertidal & 3 & $2.91 \pm 0.06$ & $14.1 \pm 0.2$ & $3.77 \pm 0.09$ & Foliose \\
\hline & Monostroma latissimum & Intertidal & 1 & 1.75 & 20.1 & 5.23 & Foliose \\
\hline & Enteromorpha intestinalis & Intertidal & 3 & $2.77 \pm 0.08$ & $13.3 \pm 0.6$ & $3.58 \pm 0.43$ & Filamentous \\
\hline & Gelidiella acerosa & Intertidal & 3 & $2.46 \pm 0.03$ & $19.4 \pm 0.4$ & $3.76 \pm 0.60$ & Coarsely branched \\
\hline & Chaetomorpha crassa & Intertidal & 3 & $2.58 \pm 0.06$ & $17.3 \pm 0.5$ & $1.75 \pm 0.54$ & Finely branched \\
\hline \multirow[t]{5}{*}{ Dabaisha } & Monostroma latissimum & Intertidal & 3 & $1.67 \pm 0.04$ & $20.4 \pm 0.5$ & $4.18 \pm 0.24$ & Foliose \\
\hline & Enteromorpha intestinalis & Intertidal & 3 & $2.58 \pm 0.03$ & $15.0 \pm 0.1$ & $2.33 \pm 0.08$ & Filamentous \\
\hline & Boodlea composite & Intertidal & 2 & $3.59 \pm 0.13$ & $12.6 \pm 0.2$ & $2.27 \pm 0.13$ & Finely branched \\
\hline & Centroceras clavulatum & Intertidal & 2 & $3.46 \pm 0.47$ & $10.4 \pm 0.5$ & $2.21 \pm 0.03$ & Finely branched \\
\hline & Yamadaella caenomyce & Intertidal & 3 & $0.90 \pm 0.01$ & $13.8 \pm 0.9$ & $4.01 \pm 0.77$ & Calcareous \\
\hline \multicolumn{8}{|c|}{ Dongsha Island } \\
\hline & $\begin{array}{l}\text { Caulerpa racemosa v. } \\
\text { macrophysa }\end{array}$ & Subtidal & 3 & $2.48 \pm 0.05$ & $19.9 \pm 0.3$ & $3.92 \pm 0.27$ & Coarsely branched \\
\hline & Halimeda discoidea & Subtidal & 1 & 0.33 & 48.8 & 2.66 & Calcareous \\
\hline & Turbinaria ornate & Subtidal & 2 & $0.74 \pm 0.49$ & $58.0 \pm 5.2$ & $3.03 \pm 0.11$ & Leathery \\
\hline & Asparagopsis taxiformis & Subtidal & 1 & 4.00 & 10.0 & 4.31 & Finely branched \\
\hline & Gracilaira canaliculata & Subtidal & 1 & 1.92 & 24.0 & 3.39 & Coarsely branched \\
\hline
\end{tabular}
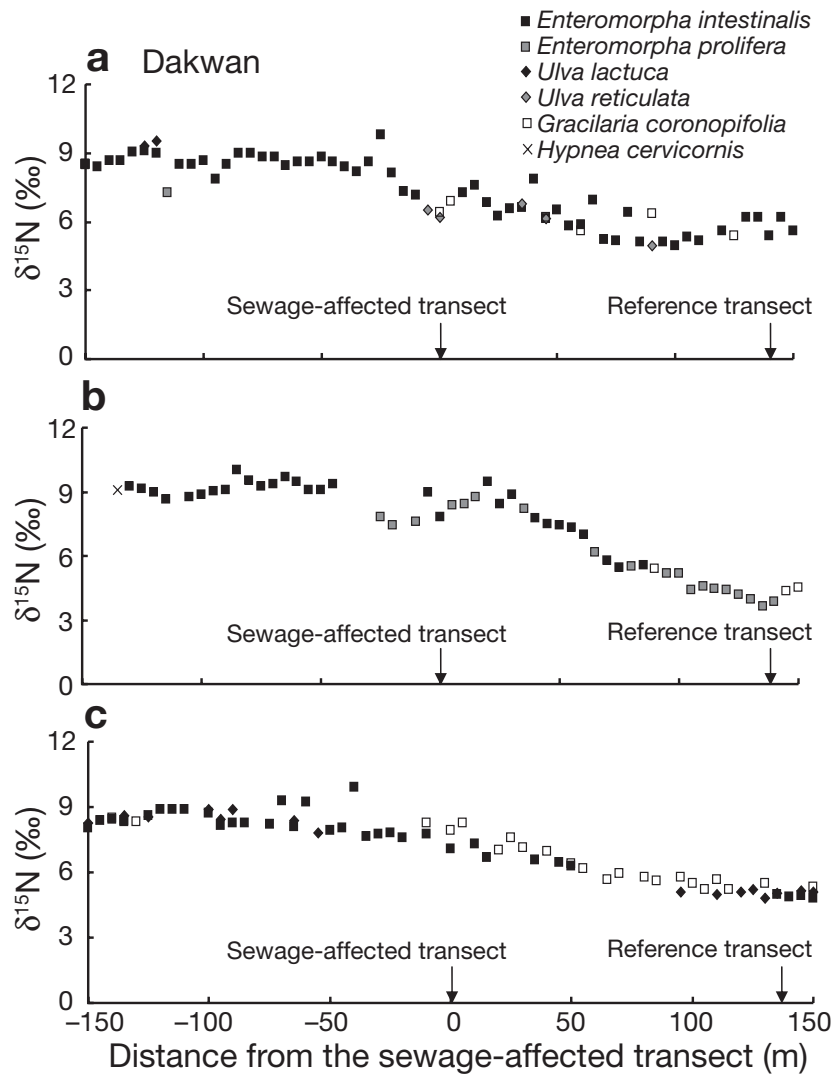

Fig. 7. $\delta^{15} \mathrm{~N}$ values of macroalgae collected from the horizontal lines, parallel to the shore at distances of (a) 7, (b) 15, and

(c) $30 \mathrm{~m}$ at Dakwan in the wet seasons of 2003 and 2005

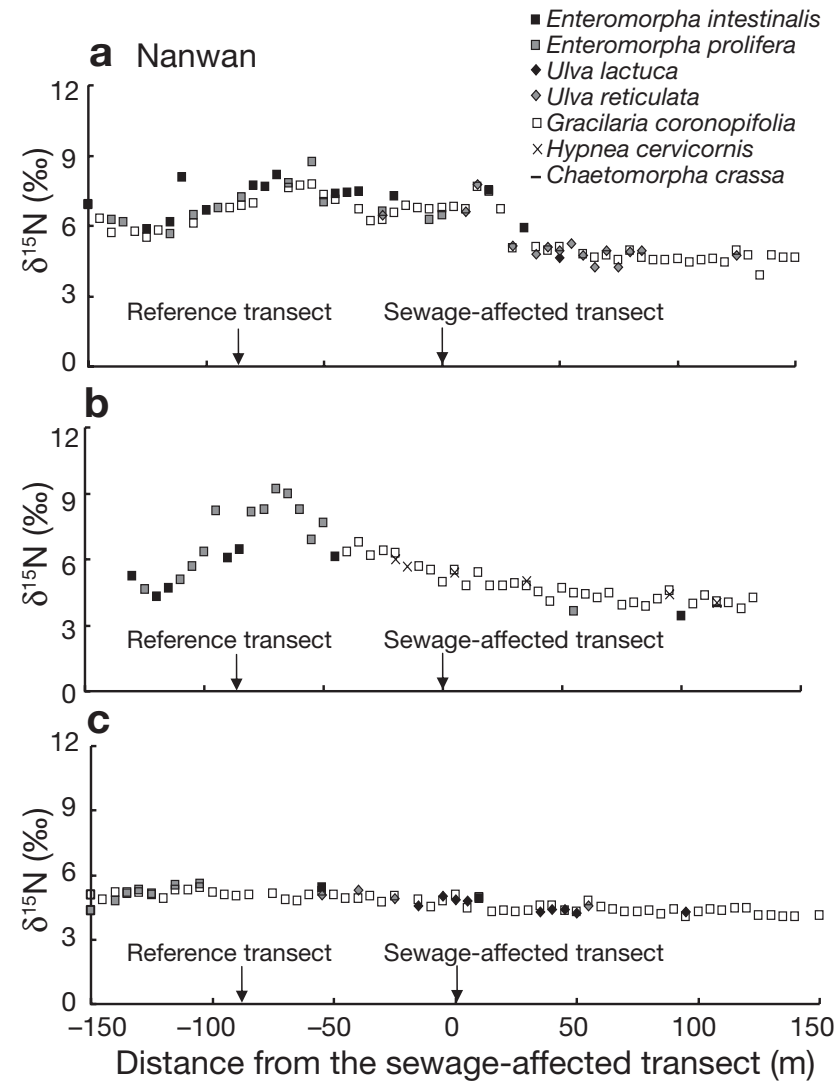

Fig. 8. $\delta^{15} \mathrm{~N}$ values of macroalgae collected from the horizontal lines, parallel to the shore at distances of (a) 7, (b) 15, and

(c) $30 \mathrm{~m}$ at Nanwan in the wet seasons of 2003 and 2005 


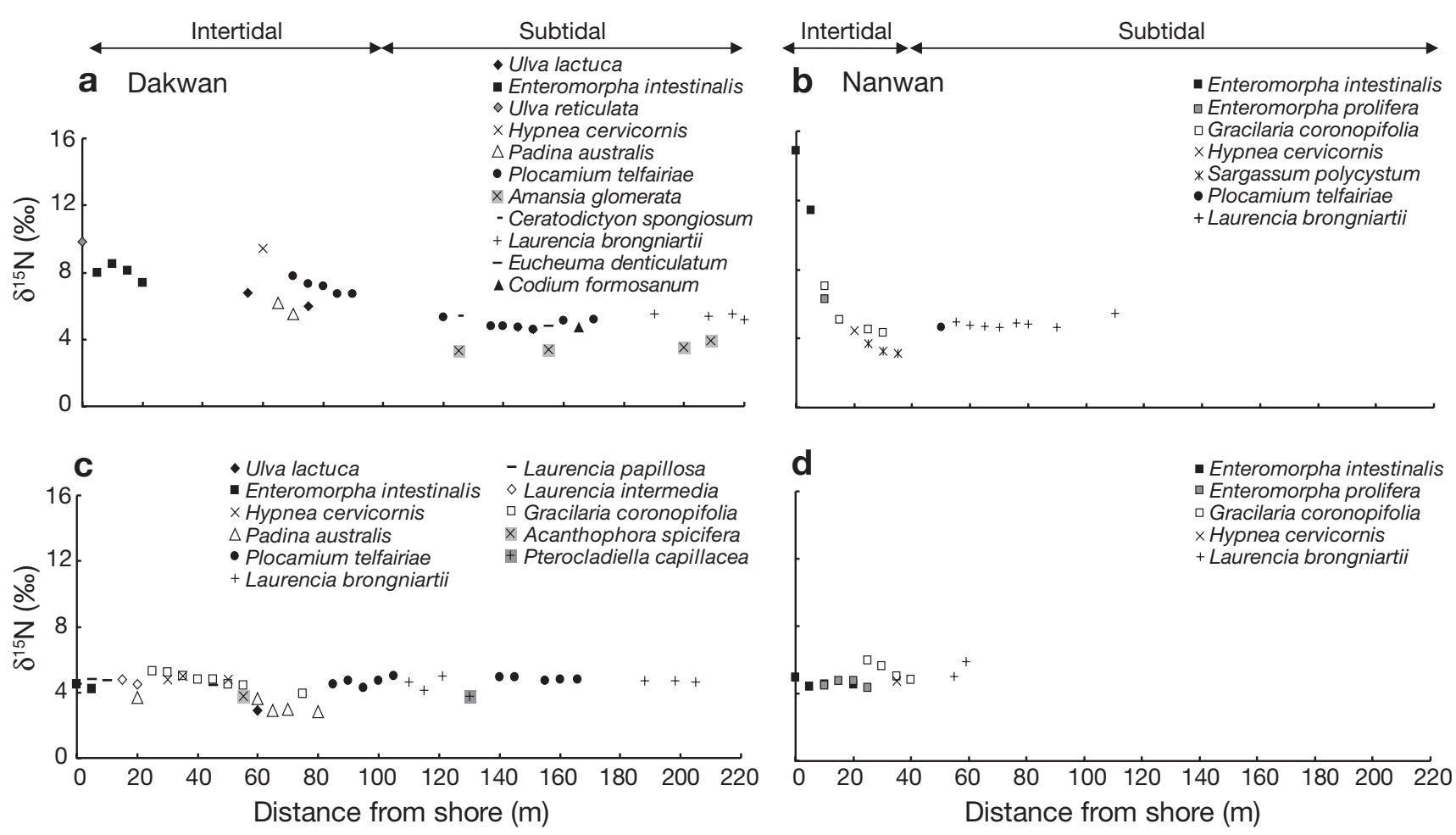

Fig. 9. $\delta^{15} \mathrm{~N}$ values of macroalgae collected from sewage-affected transects at (a) Dakwan and (b) Nanwan and from the reference transects at (c) Dakwan and (d) Nanwan in the wet season of 2002

Dakwan were significantly higher than the values of the same species growing on the reference transect, but the difference was small.

In the wet season, the curvilinear gradient of the $\delta^{15} \mathrm{~N}$ values of macroalgae growing along the sewageaffected transects at both sites was still clear (Fig. 10a,b). At Dakwan, $\delta^{15} \mathrm{~N}$ values of Enteromorpha intestinalis, Plocamium telfairiae, and Laurencia brongniartii growing on the sewage-affected transect were significantly higher than the values of the same species growing on the reference transect (Table 3). At Nanwan, however, only E. intestinalis growing on the sewage-affected transect in the intertidal zone showed significantly higher $\delta^{15} \mathrm{~N}$ values than specimens of the same species growing on the reference transect.

On the 2 pristine islands, the $\delta^{15} \mathrm{~N}$ values of macroalgae remained low at 1.75 to $5.45 \%$, regardless of the thallus form or sampling zone (Table 4). In the intertidal zone of Green Island, the $\delta^{15} \mathrm{~N}$ values of Ulva lactuca and Enteromorpha intestinalis were slightly lower than the values of the same species growing on the reference transects in Nanwan Bay (Table 2). In the subtidal zone of Dongsha Island, $\delta^{15} \mathrm{~N}$ values of Gracilaria canaliculata (Table 4) were also slightly lower than the values of $G$. coronopifolia growing in the lower intertidal zone at Nanwan (Table 3).

\section{DISCUSSION}

Yearly $\mathrm{N}$ loadings per unit length of shoreline from untreated sewage effluents into coral reefs at Dakwan (282 $\mathrm{Mg} \mathrm{N} \mathrm{km}^{-1} \mathrm{yr}^{-1}$ ) and Nanwan (46 Mg N $\mathrm{km}^{-1} \mathrm{yr}^{-1}$ ) were high and moderate, respectively, when compared with the loadings of 4 to $90 \mathrm{Mg} \mathrm{N}$ $\mathrm{km}^{-1} \mathrm{yr}^{-1}$ reported for the coral reefs of Ishigaki Island, Japan (Umezawa et al. 2002b). Concentrations of $\mathrm{NO}_{2}{ }^{-}+\mathrm{NO}_{3}{ }^{-}$in the sewage effluents at both sites were comparable to $3.4 \mu \mathrm{M}$ of wastewater of Ishigaki Island (Umezawa et al. 2002b). However, in Nanwan Bay, there were extremely high $\mathrm{NH}_{4}{ }^{+}$concentrations in the sewage effluents, and they often contributed $>90 \%$ of the composition of the DIN concentrations, which could be explained to a large extent by the number of tourists visiting the bay (Fig. $2 a)$. This is supported by our observations that the sewage flow at Dakwan was not higher in the wet season than in the dry season (Table 1). The greater monthly $\mathrm{N}$ loading at Dakwan in the dry season (from winter to spring) could be attributed to combined effects of the high density of houses and resorts and the vacation times of Chinese New Year and spring break. The $\mathrm{N}$ loading into Nanwan Bay was thus derived primarily from wastes and human feces. 

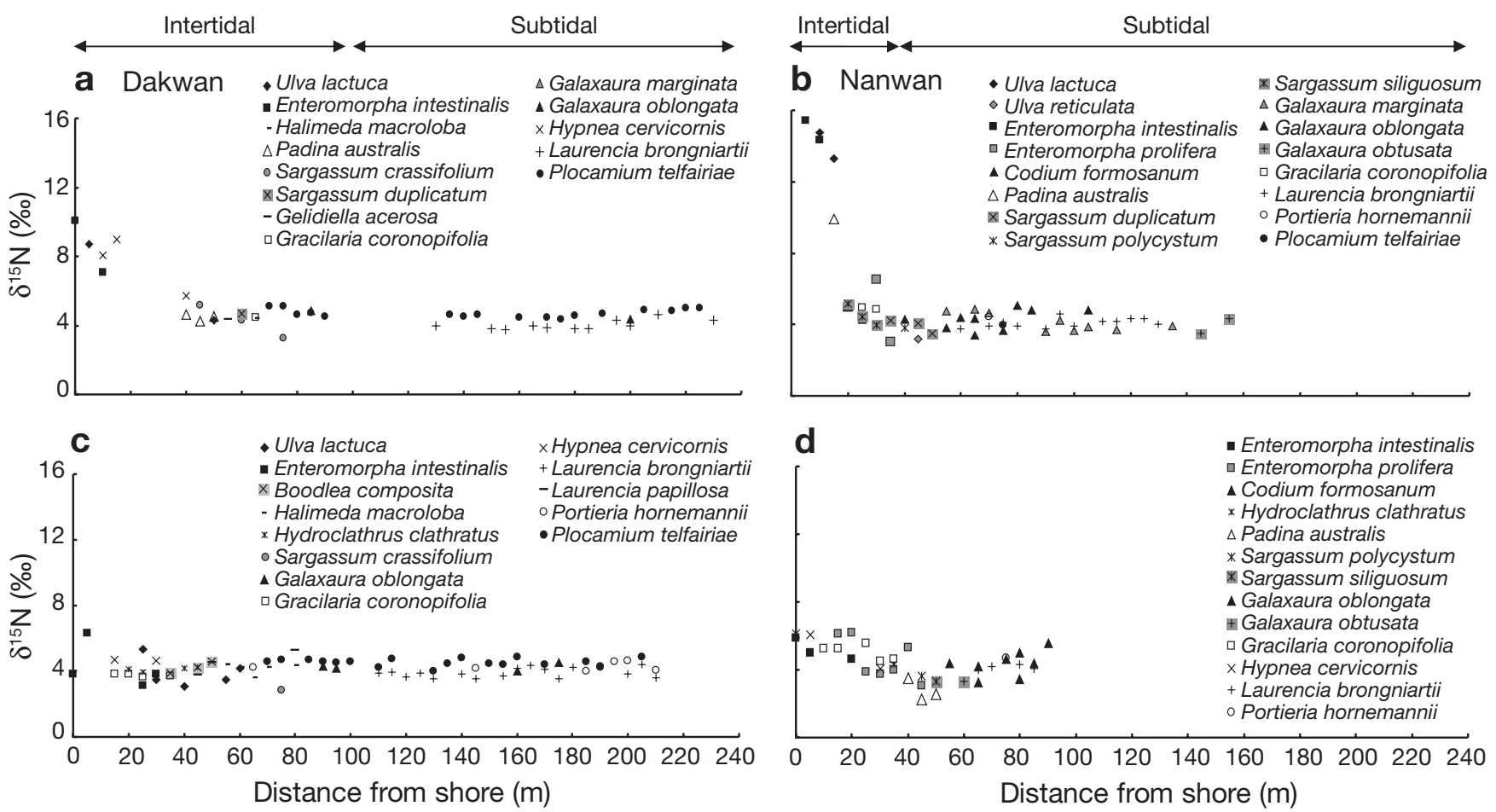

Fig. 10. $\delta^{15} \mathrm{~N}$ values of macroalgae collected from sewage-affected transects at (a) Dakwan and (b) Nanwan and from the reference transects at (c) Dakwan and (d) Nanwan in the dry season of 2003

Anthropogenic $\mathrm{N}$ enrichment is generally followed by a predicted accumulation of fast-growing opportunistic algae (Fujita 1985) and a subsequent degradation of coral reefs (Jackson et al. 2001). Koop et al. (2001) indicated that water column nutrient concentrations alone are not adequate for assessing the nutrient conditions of coral reefs due to the rapid nutrient uptake by reef organisms. Sensitive and quantifiable biological indicators for tracing anthropogenic N loadings need to be developed for coral reefs. The tissue nutrient content of macroalgae has been suggested as a more useful monitoring tool than traditional water chemistry for evaluating in situ nutrient availability (Björnsäter \& Wheeler 1990, Lyngby \& Mortensen 1994, Fong et al. 1998). In the laboratory, $\mathrm{NH}_{4}{ }^{+}$enrichment was found to increase the $\mathrm{N}$ content of 2 macroalgae, Gracilaria tenuistipitata and Ulva pertusa (Liu \& Dong 2001). However, field surveys found that not all macroalgae responded to elevated water column DIN concentrations in the same way (Umezawa et al. 2002b, Lin \& Hung 2004). Horrocks et al. (1995) suggested that tissue nutrient content is reliable as an indicator only in regions where nutrients are limiting to growth. Fong et al. (2001) indicated that the effectiveness of tissue nutrient contents of macroalgae as an indicator of nutrient availability is related to the morphological forms and nutrient sources. In this study, the $\mathrm{N}$ contents (the $\mathrm{C} / \mathrm{N}$ ratios) of macroalgae growing near the outfalls of sewer drains were not predictably elevated (or reduced). Thallus form might affect the response to sewage $\mathrm{N}$, because lower $\mathrm{N}$ contents and higher $\mathrm{C} / \mathrm{N}$ ratios were observed in macroalgae with calcareous and leathery forms. Nevertheless, the most dominant macroalga in the upper intertidal zone, Enteromorpha spp., which has simple thalli with large surface-to-volume ratios, is capable of rapid nutrient uptake (Littler \& Littler 1980). Significantly higher N contents and lower $\mathrm{C} / \mathrm{N}$ ratios were detected in Enteromorpha growing near the outfall of the sewer drain at Dakwan, where seaweeds are subjected to high rates of sewage $\mathrm{N}$ discharge (Table 2). However, the comparable tissue values were not statistically significant at Nanwan, where the seaweeds are subjected to medium rates of sewage $\mathrm{N}$ discharge. It appears that the $\mathrm{N}$ contents of macroalgae are not a sensitive indicator of $\mathrm{N}$ loading.

In addition, the $\mathrm{N}$ contents of intertidal macroalgae appear related more to air exposure than $\mathrm{N}$ loading. In Nanwan Bay, the time of seasonal low tide exposure during daylight in the upper intertidal zone averaged $7.63 \mathrm{~h}$, as compared to $0.75 \mathrm{~h}$ in the lower intertidal zone (Lan et al. 2005). At both sites, the $\mathrm{C} / \mathrm{N}$ ratios of dominant macroalgae including Enteromorpha, Ulva, and Gracilaria spp. growing on the $7 \mathrm{~m}$ lines in the upper intertidal zone remained low (Figs. 3 \& 4), and generally lower than the ratios of the same species 
growing in the middle and lower intertidal zones (Table 2). Although exposure to air will cause desiccation stress, Enteromorpha and Ulva are widely recognized as among the most stress-resistant macroalgae (Littler \& Littler 1980). Photosynthesis of Enteromorpha has been shown to benefit from atmospheric $\mathrm{CO}_{2}$ during emersion (Gao et al. 1999). The top layers of Ulva spp. mats on the water surface grow faster than the lower layers (Malta et al. 2003). Growth enhancement of Ulva by increased concentrations of $\mathrm{CO}_{2}$ is entirely dependent on $\mathrm{N}$-assimilation rates (Gordillo et al. 2001). Exposure to air may stimulate the uptake of $\mathrm{N}$ to meet the needs of growth of these intertidal macroalgae. This may explain the distinct trend of higher $\mathrm{N}$ contents and lower $\mathrm{C} / \mathrm{N}$ ratios of macroalgae growing in the upper intertidal zone.

Unlike tissue $\mathrm{N}$ contents and $\mathrm{C} / \mathrm{N}$ ratios, $\delta^{15} \mathrm{~N}$ values of Enteromorpha, Ulva, and Gracilaria spp. growing around the sewage-affected transects were significantly higher than the values of specimens of the same species growing along the reference transects in the intertidal zone (Table 2), regardless of whether the thallus was of the filamentous, foliose, or coarsely branched form. While the thallus forms of macroalgae are generally related to nutrient uptake (Littler \& Littler 1980), these 3 thallus forms might have similar physiological attributes with respect to $\mathrm{N}$ uptake and $\delta^{15} \mathrm{~N}$ values. Gartner et al. (2002) analyzed 3 morphologically distinct macroalgae with different nutrient uptake characteristics in response to sewage $N$, and found that the $\delta^{15} \mathrm{~N}$ values of macroalgae with fast nutrient uptake rates responded more quickly than did those of species with slower rates. However, they indicated that the leathery kelp Ecklonia radiata, with large amounts of structural biomass and a very low $\mathrm{N}$ uptake rate, was capable of acquiring measurably altered $\delta^{15} \mathrm{~N}$ values with longer exposure times. In this study, in addition to those macroalgae with fast nutrient uptake rates and an associated response to sewage $\mathrm{N}$, individuals of the crustose phaeophyte Padina australis (which has low nutrient uptake rates) that were exposed to sewage $\mathrm{N}$ developed remarkably higher $\delta^{15} \mathrm{~N}$ values than specimens growing along the reference transect. Our results are consistent with the findings of Gartner et al. (2002) and showed that the $\delta^{15} \mathrm{~N}$ value of macroalgae can be used to trace the sewage effluents into the coral reefs in Nanwan Bay yearround. It is clear that tissue $\delta^{15} \mathrm{~N}$ is better at detecting anthropogenic $\mathrm{N}$ loading than are tissue $\mathrm{N}$ contents and the $\mathrm{C} / \mathrm{N}$ ratios of macroalgae.

The $\delta^{15} \mathrm{~N}$ values of macroalgae in Nanwan Bay may reflect regional dispersal and the magnitude of sewage effluents, as suggested by Gartner et al. (2002). At both sites, the higher $\delta^{15} \mathrm{~N}$ values of macroalgae growing along the sewage-affected transects in the upper inter- tidal zone indicate strong effects of sewage effluents. There was a decline in the $\delta^{15} \mathrm{~N}$ values of macroalgae in the lower intertidal zone, indicating a reduction by water flushing of the influence of sewage $\mathrm{N}$. The higher $\delta^{15} \mathrm{~N}$ values of Enteromorpha on the west side of the sewage-affected transect at Nanwan (Fig. 8) indicate a site of groundwater seepage of sewage effluents, where the limestone ground of the coast is permeable.

The spatial pattern of asymmetrically higher $\delta^{15} \mathrm{~N}$ values of macroalgae on the south side of the horizontal lines at Dakwan was in accordance with the circulation patterns in Nanwan Bay (Lee et al. 1999). Sewage effluents might be accumulating on the west side of Nanwan Bay through the effects of ebbinduced cyclonic circulation and blockage by the western cape, but not on the east side because an anticyclonic circulation during flood tides is largely absent (Fig. 1). The circulation pattern in the bay, combined with the much higher loading rates of sewage effluents, might also explain the more-enriched $\delta^{15} \mathrm{~N}$ values of intertidal macroalgae growing at Dakwan (Table 2). On the other hand, the absence of land masses on the western side of the sewage-affected transect at Nanwan might explain the lower $\delta^{15} \mathrm{~N}$ values of the same species in the intertidal zone, even on the sewageaffected transect, because sewage effluents at a distance of $30 \mathrm{~m}$ from the coastline are flushed rapidly out to sea by the daily cyclonic circulation.

Despite differences in the $\mathrm{N}$ loading rate and circulation characteristics, the 2 sites $3 \mathrm{~km}$ apart showed the same curvilinear gradient in macroalgal tissue $\delta^{15} \mathrm{~N}$, decreasing from the outfall of the sewer to the subtidal zone along the sewage-affected transect, suggesting that the cause was not local. In a transect study across the Great Barrier Reef, Sammarco et al. (1999) demonstrated a significant parabolic relationship between $\delta^{15} \mathrm{~N}$ of the scleractinian coral Porites lobata and the distance from shore, with the highest values of 5.0 to $5.5 \%$ inshore, the lowest values of about $3.8 \%$ on the mid-shelf about $60 \mathrm{~km}$ from shore, and high values of $5.2 \%$ again offshore. This spatial pattern of $\delta^{15} \mathrm{~N}$ values was attributed to inputs of different $\mathrm{N}$ sources. They suggested that inshore corals receive their $\mathrm{N}$ primarily from terrestrial sources, while mid-shelf corals receive some of their $\mathrm{N}$ from associated algal mats possessing high rates of $\mathrm{N}$ fixation, and offshore corals receive their $\mathrm{N}$ from seasonal, nutrientrich, cold-water intrusions or upwellings. $\mathrm{N}$ fixation might be an important $\mathrm{N}$ source in oligotrophic coral reefs (Bell et al. 1999). In the intertidal zone of Nanwan Bay, N fixation activity by the zoanthid Palythoa tuberculosa has been detected under both aerobic and anaerobic conditions, but fixed $\mathrm{N}$ as the sole $\mathrm{N}$ source only occurred under anaerobic conditions (Shieh \& Lin 
1992). Since oxygen saturation in the water column averaged $117 \%$ (Chen et al. 2005), the isotopically light inputs derived from $\mathrm{N}$ fixation are unlikely to have affected the sewage signal along the sewageaffected transects. The $\delta^{15} \mathrm{~N}$ values of macroalgae growing on the reference transects in the intertidal zones (Figs. 9 \& 10) and around Green Island (Table 4) were generally consistent with values of mid-shelf corals on the Great Barrier Reef that receive some of their $\mathrm{N}$ via atmospheric $\mathrm{N}$ fixation (Sammarco et al. 1999). Sewage-derived wastewater DIN is typically enriched in $\delta^{15} \mathrm{~N}$ by 10 to $22 \%$ (Heaton 1986). The distinctly higher $\delta^{15} \mathrm{~N}$ values of macroalgae at the outfalls of sewer drains at both sites, by 6 to $10 \%$, relative to the $\delta^{15} \mathrm{~N}$ values of the macroalgae growing on the reference transects and around the 2 pristine islands, make sewage $\mathrm{N}$ responsible for much of the observed enrichment in $\delta^{15} \mathrm{~N}$ on the sewage-affected transects. In the subtidal zone of Nanwan Bay, there is a daily upwelling during the spring tides (Lee et al. 1999). $\mathrm{NO}_{3}{ }^{-}$concentrations in the water column ranged from $<0.15$ to $10.2 \mu \mathrm{M}$, and showed a negative correlation with temperature (Chen et al. 2005). Although N uptake by subtidal macroalgae may be controlled by low light, and depletion in $\delta^{15} \mathrm{~N}$ values might occur, the fractionation in Nanwan Bay might be within $2 \%$, due to the shallow distribution depth of $<30 \mathrm{~m}$ (Heikoop et al. 1998) and the clear water (Chen et al. 2005). $\delta^{15} \mathrm{~N}$ values of macroalgae in the subtidal zone at both sites thus matched the values of offshore corals receiving their $\mathrm{N}$ from upwellings and the typical value of $4.6 \%$ of $\mathrm{NO}_{3}{ }^{-}$in the intermediate water (Liu \& Kaplan 1989). This may explain why the $\delta^{15} \mathrm{~N}$ values of the subtidal macroalgae growing in Nanwan Bay were more enriched than those growing in the subtidal zone of Dongsha Island without upwelling.

The lack of elevated $\delta^{15} \mathrm{~N}$ values, high $\mathrm{N}$ contents, and lower $\mathrm{C} / \mathrm{N}$ ratios in macroalgae growing in the lower intertidal zone and the subtidal zone of the sewage-affected transects on both sides of the coast of Nanwan Bay may indicate that the large volume of sewage effluents flowing into the bay experiences a quick tidal mixing, due to the daily cyclonic circulation and short water residence time of $<1 \mathrm{~d}$ (cf. Umezawa et al. 2002b). Consequently, the anthropogenic $\mathrm{N}$ load is rapidly flushed out of the lower intertidal zone, and there is little evidence showing that it reaches coral reefs in the subtidal zone. Indeed, the $\mathrm{NO}_{3}{ }^{-}$flux (3.68 $\mathrm{kg} \mathrm{N} \mathrm{m}^{-2} \mathrm{yr}^{-1}$ ) from upwelling in the bay (P.-J. Meng unpubl. data) was higher by 4 orders of magnitude than the land-derived DIN loading $(8.16 \times$ $10^{-4} \mathrm{~kg} \mathrm{~N} \mathrm{~m}^{-2} \mathrm{yr}^{-1}$ ). Low $\delta^{15} \mathrm{~N}$ values of macroalgae in the lower intertidal and subtidal zones imply that anthropogenic $\mathrm{N}$ enrichment might not, in itself, be sufficient to stimulate the transition from coral-domi- nance to fleshy macroalgal-dominance in Nanwan Bay (Dai 1993). Our results do not support the hypothesis that anthropogenic $\mathrm{N}$ enrichment is the major cause of the prolific growth of macroalgae in the bay. Similarly, the Enrichment of Nutrient on a Coral Reef Experiment (ENCORE) conducted on the Great Barrier Reef had little success in stimulating phase shifts from coraldominance to fleshy macroalgae-dominance (Koop et al. 2001). Bellwood et al. (2004) identified 3 functional groups on the reef, including bioeroders, scrapers, and grazers, which are critical for resisting phase shifts from coral-dominance to degraded systems in the face of disturbance. Other factors that lead to coral death or reduced levels of herbivory, which would leave more substratum open for algal colonization or make the effects of low-level enrichment more severe, might be more important (cf. Szmant 2002).

Acknowledgements. This study was partly supported by the National Science Council, Taiwan under grant numbers NSC90-2621-B-005-008 and NSC94-2621-B-005-006, and by the Center for Marine Bioscience and Biotechnology at NTOU. The authors thank Mr. Pi-Jen Liu for help collecting macroalgal specimens in the subtidal zone. Comments by anonymous reviewers were helpful in revising the manuscript.

\section{LITERATURE CITED}

Bell PRF, Elmetri I, Uwins P (1999) Nitrogen fixation by Trichodesmium spp. in the Central and Northern Great Barrier Reef Lagoon: Relative importance of the fixed-nitrogen load. Mar Ecol Prog Ser 186:119-126

Bellwood DR, Hughes TP, Folke C, Nyström M (2004) Confronting the coral reef crisis. Nature 429:827-933

Björnsäter BR, Wheeler PA (1990) Effect of nitrogen and phosphorus supply on growth and tissue composition of Ulva fenestrate and Enteromorpha intestinalis (Ulvales, Chlorophyta). J Phycol 26:603-611

Chen ACT, Wang BJ, Hsing LY (2004) Upwelling and degree of nutrient consumption in Nanwan Bay, Southern Taiwan. J Mar Sci Tech 12:442-447

Chen CC, Shiah FK, Lee HJ, Li KY, Meng PJ, Kao SJ, Tseng YF, Chung CL (2005) Phytoplankton and bacterioplankton biomass, production and turnover in a semi-enclosed embayment with spring tide induced upwelling. Mar Ecol Prog Ser 304:91-100

Clarke KR, Warwick RM (1994) Changes in marine communities: an approach to statistical analysis and interpretation. Natural Environment Research Council, Plymouth Press, UK

Dai CF (1993) Patterns of coral distribution and benthic space partitioning on the fringing reefs of Southern Taiwan. PSZN I: Mar Ecol 14:185-204

Done TJ (1992) Phase shifts in coral reef communities and their ecological significance. Hydrobiologia 247:121-132

Fong P, Boyer KE, Zedler JB (1998) Developing an indicator of nutrient enrichment in coastal estuaries and lagoons using tissue nitrogen content of the opportunistic alga, Enteromorpha intestinalis (L. Link). J Exp Mar Biol Ecol 231: $63-79$ 
Fong P, Kamer K, Boyer KE, Boyle KA (2001) Nutrient content of macroalgae with differing morphologies may indicate sources of nutrients for tropical marine systems. Mar Ecol Prog Ser 220:137-152

Fry B (1999) Using stable isotopes to monitor watershed influences on aquatic trophodynamics. Can J Fish Aquat Sci 56:2167-2171

Fujita RM (1985) The role of nitrogen status in regulating transient ammonium uptake and nitrogen storage by macroalgae. J Exp Mar Biol Ecol 92:283-301

Gao K, Ji Y, Aruga Y (1999) Relationship of $\mathrm{CO}_{2}$ concentrations to photosynthesis of intertidal macroalgae during emersion. Hydrobiologia 398-399:355-359

Gartner A, Lavery P, Smit AJ (2002) Use of $\delta^{15} \mathrm{~N}$ signatures of different functional forms of macroalgae and filter-feeders to reveal temporal and spatial patterns in sewage dispersal. Mar Ecol Prog Ser 235:63-73

Gearing JN (1991) The study of diet and trophic relationships through natural abundance ${ }^{13} \mathrm{C}$. In: Coleman DC, Firy B (eds) Carbon isotope techniques. Academic Press, New York, p 201-218

Gordillo FJL, Niell FX, Figueroa FL (2001) Non-photosynthetic enhancement of growth by high $\mathrm{CO}_{2}$ level in the nitrophilic seaweed Ulva rigida C. Agardh (Chlorophta). Planta 213:64-70

Grigg RW (1995) Coral reefs in an urban embayment in Hawaii: a complex case history controlled by natural and anthropogenic stress. Coral Reefs 14:253-266

Heaton THE (1986) Isotopic studies of nitrogen pollution in the hydrosphere and atmosphere. A review. Chem Geol Isot Geosci Sect 59:87-102

Heikoop JM, Dunn JJ, Risk MJ, Sandeman IM, Schwarcz JP, Waltho N (1998) Relationship between light and the $\delta^{15} \mathrm{~N}$ of coral tissue: examples from Jamaica and Zanzibar. Limnol Oceanogr 43:909-920

Heikoop JM, Risk MJ, Lazier AV, Edinger EN and 5 others (2000) Nitrogen-15 signals of anthropogenic nutrient loading in reef corals. Mar Pollut Bull 40:628-636

Horrocks JL, Stewart GR, Dennison WC (1995) Tissue nutrient content of Gracilaria spp. (Rhodophyta) and water quality along an estuarine gradient. Mar Freshw Res 46: 975-983

Hughes TP (1994) Catastrophes, phase shifts, and large-scale degradation of a Caribbean coral reef. Science 265: $1547-1551$

Jackson BC, Kirby MX, Berger WH, Bjorndal KA and 15 others (2001) Historical overfishing and the recent collapse of coastal ecosystem. Science 293:629-638

Jones AB, O'Donohue MJ, Udy J, Dennison WCD (2001) Assessing ecological impacts of shrimp and sewage effluent: biological indicators with standard water quality analyses. Estuar Coast Shelf Sci 52:91-109

Koop K, Booth D, Broadbent A, Brodie J and 16 others (2001) ENCORE: The effect of nutrient enrichment on coral reefs. Synthesis of results and conclusions. Mar Pollut Bull 42: 91-120

Lan CY, Kao WY, Lin HJ, Shao KT (2005) Measurement of chlorophyll fluorescence reveals mechanisms for habitat niche separation of the intertidal seagrasses Thalassia hemprichii and Halodule uninervis. Mar Biol 148: 25-34

Lapointe BE (1997) Nutrient thresholds for bottom-up control of macroalgal blooms on coral reefs in Jamaica and southeast Florida. Limnol Oceanogr 42:1119-1131

Lee HJ, Chao SY, Fan KL (1999) Flood-ebb disparity of tidally induced recirculation eddies in a semi-enclosed basin: Nan Wan Bay. Cont Shelf Res 19:871-890

Lin HJ, Hung JJ (2004) Factors affecting macroalgal distribution in a eutrophic tropical lagoon in Taiwan. Mar Biol 144: 653-664

Lin HJ, Shao KT (1998) Temporal changes in the abundance and growth of intertidal Thalassia hemprichii seagrass beds in southern Taiwan. Bot Bull Acad Sin 39:191-198

Littler MM, Littler DS (1980) The evolution of thallus form and survival strategies in benthic marine macroalgae: field and laboratory tests of a functional form model. Am Nat 116:25-44

Liu JW, Dong SL (2001) Comparative studies on utilizing nitrogen capacity between two macroalgae Gracilaria tenuistipitata var. liui (Rhodophyta) and Ulva pertusa (Chlorophyta). I. Nitrogen storage under nitrogen enrichment and starvation. J Environ Sci 13:318-322

Liu KK, Kaplan IR (1989) The eastern tropical Pacific as a sources of ${ }^{15} \mathrm{~N}$-enriched nitrate in seawater off southern California. Limnol Oceanogr 34:820-830

Lyngby JE, Mortensen SM (1994) Assessment of nutrient availability and limitation using macroalgae. J Aquat Ecosyst Health 3:27-34

Malta E, Rijstenbil JW, Brouwer PEM, Kromkamp JC (2003) Vertical heterogeneity in physiological characteristics of Ulva spp. mats. Mar Biol 143:1029-1038

McClelland JW, Valiela I, Michener RH (1997) Nitrogenstable isotope signatures in estuarine food webs: a record of increasing urbanization in coastal watersheds. Limnol Oceanogr 42:930-937

McCook LJ, Jompa J, Diaz-Pulido G (2001) Competition between corals and algae on coral reefs: a review of evidence and mechanisms. Coral Reefs 19:400-417

Pai SC, Yang CC (1990) Formation kinetics of the pink azo dye in the determination of nitrite in natural water. Anal Chim Acta 232:345-349

Sammarco PW, Risk MJ, Schwarcz HP, Heikoop JM (1999) Cross-continental shelf trends in coral $\%{ }^{15} \mathrm{~N}$ on the Great Barrier Reef: further consideration of the reef nutrient paradox. Mar Ecol Prog Ser 180:131-138

Shieh WY, Lin YM (1992) Nitrogen fixation (acetylene reduction) associated with the zoanthid Palythoa tuberculosa Esper. J Exp Mar Biol Ecol 163:31-41

Smith VR, Kimerer WJ, Laws EK, Brock RE, Walsh TW (1981) Kaneohe Bay sewage diversion experiment: perspectives on ecosystem responses to nutrient perturbation. Pac Sci 35:379-402

Strickland JD, Parsons TR (1972) A practical handbook of seawater analysis, 2nd edn. Fish Res Board Canada, Ottawa

Szmant AM (2002) Nutrient enrichment on coral reefs: is it a major cause of coral reef decline? Estuaries 25:743-766

Umezawa Y, Miyahima T,Kayanne H, Koike I (2002a) Significance of groundwater nitrogen discharge into coral reefs at Ishigaki Island, southwest of Japan. Coral Reefs 21: 346-356

Umezawa Y, Miyahima T, Yamamuro M, Kayanne H, Koike I (2002b) Fine-scale mapping of land-derived nitrogen in coral reefs by $\delta^{15} \mathrm{~N}$ in macroalgae. Limnol Oceanogr 47 : 1405-1416

Submitted: April 15, 2005; Accepted: September 18, 2006

Proofs received from author(s): March 22, 2007
Editorial responsibility: Charles Birkeland (Contributing

Editor), Honolulu, Hawaii, USA 